


\title{
Centimeter
}

L

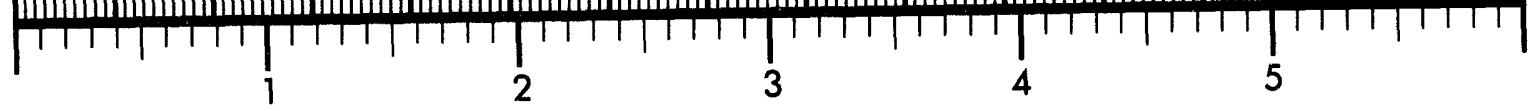
Inches


MANUFACTURED TO AIIM STANDARDS

BY APPLIED IMAGE, INC.

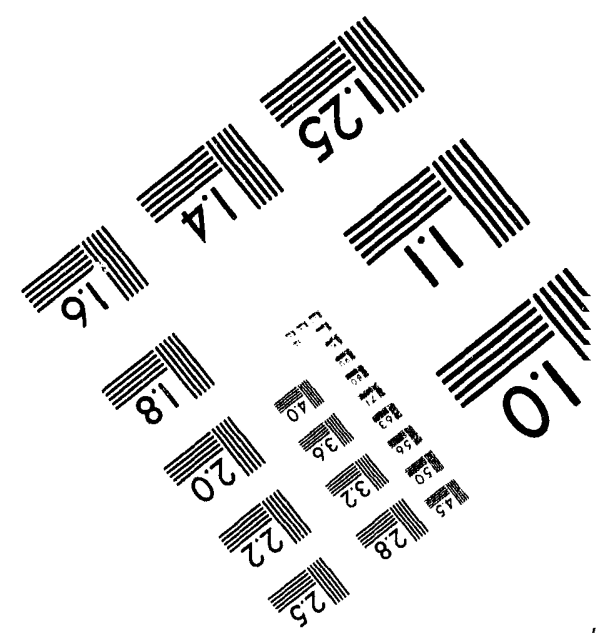



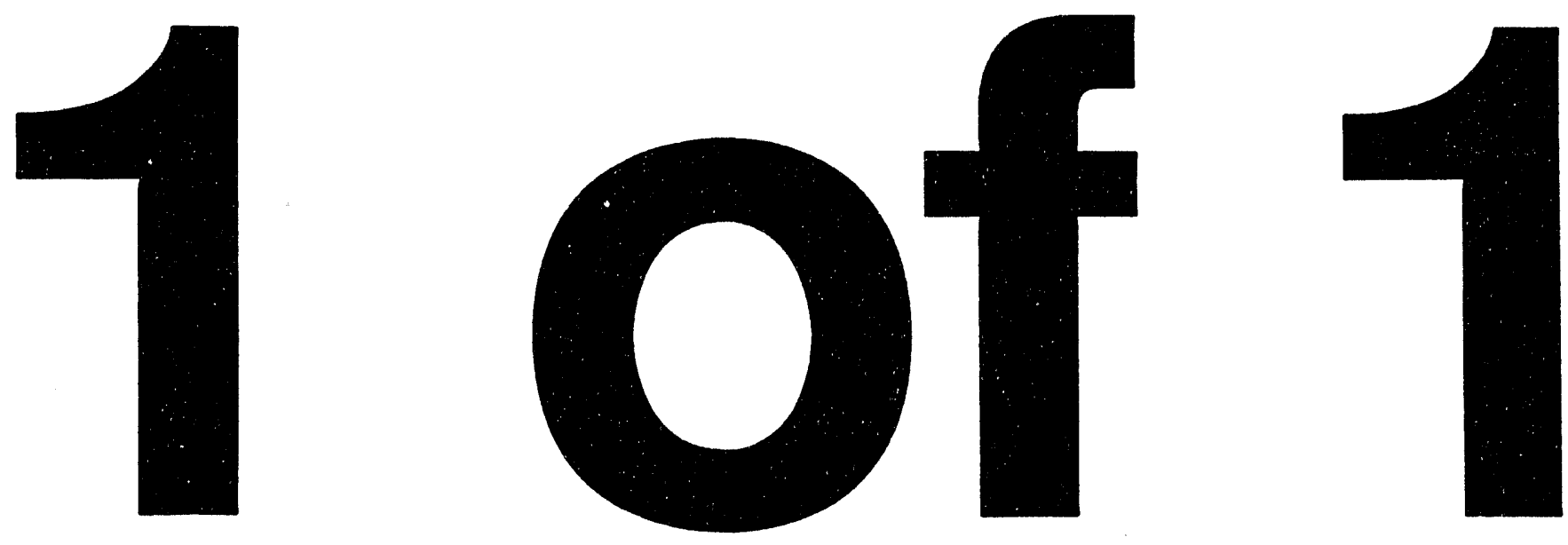
Distribution Category UC-400

UC-401

SAND93-1039

Unlimited Release

Printed July 1993

\title{
HYDROUS METAL OXIDE CATALYSTS FOR OXIDATION OF HYDROCARBONS
}

\author{
James E. Miller \\ Robert. G. Dosch \\ Linda I. McLaughlin \\ Process Research Department \\ Sandia National Laboratories, New Mexico
}

\begin{abstract}
This report describes work performed at Sandia under a CRADA with Shell Development of Houston, Texas aimed at developing hydrous metal oxide (HMO) catalysts for oxidation of hydrocarbons. Autoxidation as well as selective oxidation of 1-octene was studied in the presence of HMO catalysts based on known oxidation catalysts. The desired reactions were the conversion of olefin to epoxides, alcohols, and ketones. HMOs seem to inhibit autoxidation reactions, perhaps by reacting with peroxides or radicals. Attempts to use HMOs and metal loaded HMOs as epoxidation catalysts were unsuccessful, although their utility for this reaction was not entirely ruled out. Likewise, alcohol formation from olefins in the presence of HMO catalysts was not achieved. However, this work led to the discovery that acidified HMOs can lead to carbocation reactions of hydrocarbons such as cracking. An HMO catalyst containing $\mathrm{Rh}$ and $\mathrm{Cu}$ that promotes the reaction of $\alpha$-olefins with oxygen to form methyl ketones was identified. Although the activity of the catalyst is relatively low and isomerization reactions of the olefin simultaneously occur, results indicate that these problems may be addressed by eliminating mass transfer limitations. Other suggestions for improving the catalyst are also made.
\end{abstract}

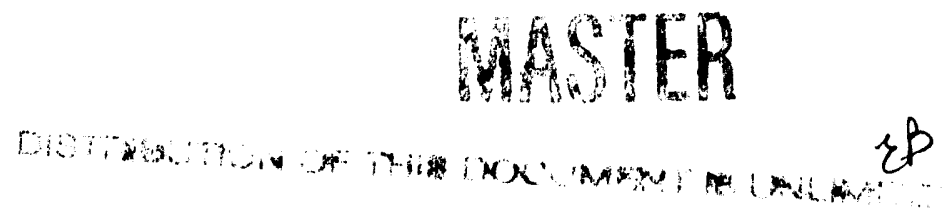




\section{HYDROUS METAL OXIDE CATALYSTS FOR OXIDATION OF HYDROCARBONS}

\section{Introduction}

This document describes work performed under a cooperative research and development agreement (CRADA) between Sandia National Laboratories, Albuquerque, New Mexico, and Shell Development Company of Houston, Texas. The goal of the work was to development hydrous metal oxide (HMO) catalysts for the synthesis of oxidized products with the larger goal of reducing energy consumption and waste generation in the chemical industry.

The appruach taken in the initial work was to screen a large number of HMO catalysts based on known oxidation catalysts. In this manner, catalysts that might be successfully developed could rapidly be identified. Once identified these catalysts could then be studied in more detail and developed more fully.

The model reaction chosen for the screening work was suggested by Shell based on their own interests, needs, and experience as well as ease of experimental execution and data interpretation. The reaction was the low temperature liquid phase oxid? ion of the linear $\alpha$-olefin 1-octene. Desirer products include epoxides, alcohols, and ketones. These classes of products or derivatives of them are used as detergents, surfactants, polymers, plasticizers, lubricating oils, and other specialty products.

\section{Experimental Setup and Operation}

The catalyst screening unit consists of four small reaction vessels and an associated gas flow system (Figure 1). The reactors are operated at ambient pressure with a liquid hydrocarbon serving as the substrate (1-octene for this work) and $10 \%$ oxyzen in nitrogen serving as the oxidant. The oxygen feed is diluted with nitrogen to avoid operating in the flammable region since the hydrocarbon substrates are flammable liquids with low flash points. The screening unit is designed to operate anywhere from room temperature to the boiling point of the substrate. Nitrogen gas is used to purge the system.

Each cylinder, $\mathrm{N}_{2}$ and $\mathrm{O}_{2} / \mathrm{N}_{2}$, has a forward regulator immediately downstream followed by a pressure relief valve and a shutoff valve. The gases then enter stainless steel flex hoses which are connected to the system via quick connects. The system has shutoff valves downstream from the quick connects. Fine metering valves are used for flow control of each gas. Downstream of the metering valves, a 3-port 2-way valve allows selection of one of the streams for flow to the reactor. The selected stream flows through a check valve into a 4-port manifold. Each port of the manifold is equipped with its own shutoff valve. The 1/16" lines leaving the ports of the manifold flow directly into the reactors.

Each reactor consists of a $1 / 4$ " stainless steel Swagelok tee with the two opposite ends capped and a short run of tubing extending from the branch. The tubing is capped by an Ultra-torr tee. The upper end of the tee is sealed with a standard GC septum and the branch supports a condenser fashioned from $1 / 4$ " stainless steel tubing which is wrapped tightly with $1 / 8$ " copper 
tubing and insulated. The $1 / 16^{\prime \prime}$ stainless steel line from the gas manifold feeds through the septum and run of 1/4" tubing and terminates inside the Swagelok tee. The line is positioned so it will be below the liquid level of the reactor to provide gas/liquid mixing and agitation. The o-ring style seals of the Ultra-torr union provide a pressure relief mechanism as they will not hold more than several pounds of pressure.

The reactors are electrically heated with mantles that fit around the reactor tees. Variacs are used to control the temperature of the reactors which are monitored with thermocouples that pass through the septum to the bottom of the reactors. The condensers are cooled by a recirculating bath capable of operating at temperatures as low as $-20^{\circ} \mathrm{C}$.

A typical experiment would proceed as follows. The catalyst is weighed out and loaded into the reactor tee. The reactor is then fully assembled and purged with nitrogen for several minutes. Making sure the condensers are adequately chilled, approximately $2 \mathrm{ml}$ of the solution containing the hydrocarbon substrate is introduced into the reactor through the septum by syringe. To prevent the vent gas from forming flammable mixtures with air, the temperature of the condenser should be below $23^{\circ} \mathrm{C}$ for 1 -octene. However, the recirculating bath is generally run at $-20^{\circ} \mathrm{C}$ to minimize the loss if volatiles from the system. The heating mantles are then used to bring the reactor to the desi ed operating temperature. The reactors are generally operated at or near the boiling point of the solutions they contain.

When the reactors are at the desired operating temperature, oxygen is introduced into the reactors by switching the 3-port valve from $\mathrm{N}_{2}$ to $\mathrm{O}_{2} / \mathrm{N}_{2}$ and adjusting the needle valve. A bubble meter may be used to measure the flow rate at each reactor vent. Liquid samples of $10 \mu l$ are periodically withdrawn by micro syringe and diluted in $1 \mathrm{cc}$ of $\mathrm{CS}_{2}$. These samples are analyzed by gas chromatography using a $30 \mathrm{~m}$ SPB5 column. A mass spectrometer is used in conjunction with the $\mathrm{GC}$ to aid in the identification of unknown reaction products. The reactors are shut down by switching the 3-port valve back to nitrogen flow and turning off the power to the variac.

Practical grade 1-octene from Eastman Kodak Company and absolute ethanol were used as received in this work; no attempts were made to remove any peroxides or other impurities that might have been present. Unless otherwise noted, the experiments were carried out with $2 \mathrm{ml}$ samples of hydrocarbon solution and $100 \mathrm{mg}$ of a hydrous titanium oxide (HTO) catalyst containing $2 \mathrm{wt} \%$ metal loading.

\section{Autoxidation}

As a baseline test for our system performance, 1-octene was oxidized in the absence of any added catalyst. These experiments were carried out at $110^{\circ} \mathrm{C}$ for periods of 6 to $12 \mathrm{hrs}$ which gave overall conversions of about $1-3 \%$. The 12 hour runs were carried out over two days with the reactor being shut down overright and reheated the next day. The products of the autoxidations were typically $30-50 \% 1,2$ epoxyoctane, and $50-70 \%$ other, less desirable, products such as 1-octen-3-one and 1-octene-3-ol. Any effect the steel reactors may have had on the reaction was minimal as similar results were obtained when the stainless steel reactor was replaced with a glass vessel. 
Autoxidations are known to occur through free radical mechanisms. Typical reaction pathways are shown below [1].



Termination

$\mathrm{RO}_{2} \cdot+\mathrm{RO}_{2} \cdot \longrightarrow \mathrm{RO}_{4} \mathrm{R} \longrightarrow$ Products $+\mathrm{O}_{2}$

Autoxidations are often carried out in the presence of metals that act as initiators or catalysts by decomposing peroxides [1].

$$
\begin{gathered}
\mathrm{RO}_{2} \mathrm{H}+\mathrm{M}^{n+} \longrightarrow \mathrm{RO}_{2}^{\prime}+\mathrm{M}^{(n-1)+}+\mathrm{H}^{+} \\
\mathrm{RO}_{2} \mathrm{H}+\mathrm{M}^{n+} \longrightarrow \mathrm{RO}_{2}^{\prime}+\mathrm{M}(\mathrm{n}-1)++\mathrm{H}^{+} \\
\mathrm{RO}_{2} \mathrm{H}+\mathrm{M}^{(n-1)+} \longrightarrow \mathrm{RO}^{\prime}+\mathrm{M}^{n+}+\mathrm{OH}^{-} \\
\mathrm{M}=\text { Group VII, VIII, IB }
\end{gathered}
$$


As manganese is often the metal of choice for catalyzing autoxidations [2], Mn from the sulfate was exchanged onto several different support materials including the crystalline silico-titanates designated DG61, and SNLTAM5\#60 [3]. Table I summarizes the different Mn catalysts that were studied in this work along with other autoxidation experiments. The experiments were performed as described above with $100 \mathrm{mg}$ of catalyst and $2 \mathrm{ml}$ of 1-octene. Surprisingly, no reaction products were observed for any of the Mn systems tested except the Mn loaded crystalline silico-titanates that had been calcined at 250 or $500^{\circ} \mathrm{C}$. For those systems, the product distribution and activity resembled that realized in the absence of catalyst; suggesting that the catalyst was not influencing the system in any way. Consistent with this conclusion is the fact that no difference was observed between catalysts loaded with a few percent of $\mathrm{Mn}$, and some which were prepared from a solution containing a large excess of $\mathrm{Mn}$. As certain sulfur compounds are known to inhibit autoxidation [4], experiments were run in the presence of the unexchanged, uncalcined amorphous and crystalline supports. Interestingly, no reaction products were observed indicating that the lack of oxidation products was not due to sulfur contamination. An experiment was also performed with unexchanged, calcined DG61. Again no reaction products were observed.

As the desired function of $\mathrm{Mn}$ in these catalysts was to decompose peroxides, a simple qualitative test was performed to test their ability to do so. Several drops of $3 \% \mathrm{H}_{2} \mathrm{O}_{2}$ were added to a few $\mathrm{mg}$ of catalyst and the resulting reaction observed. Rapid decomposition of the peroxide as evidenced by gas evolution was observed for the uncalcined Mn DG61 catalyst. The observed rate of decomposition for the calcined Mn DG61 material was significantly less. This result, coupled with the fact that autoxidation products were not observed over the unexchanged, calcined crystalline material, but were observed over the exchanged, calcined crystalline material, suggests that the Mn somehow interacted strongly with the crystalline support upon calcination.

Several possibilities could account for the lack of autoxidation products in the presence of HTOs and related crystalline materials. One possibility is that the oxygenated products simply bind to the HTOs thereby preventing their observation. This possibility was explored by adding $50 \mathrm{mg}$ of $\mathrm{Mn}\left(\mathrm{Na}_{0.5} \mathrm{~T}^{\mathrm{T}}-\mathrm{Si}_{0.2}\right)$ to a reactor after autoxidation had been carried out and observing the effect on the concentration of the autoxidation products. As no effect was observed, this possibility was ruled out.

A second explanation for the lack of products is that autoxidation reactions occurred but the catalysts caused further reactions of the products to compounds that were not retained in the system. Consesutive reactions that could lead to this result include combustion to $\mathrm{CO}_{2}$ and water, or cracking reactions leading to lighter hydrocarbons. This possibility was explored by spiking 1-octene with 2\% 1,2 epoxyoctane and running the reaction as before for 9-10 hrs in the presence of amorphous and as prepared crystalline Mn catalysts. Initial decreases in the epoxide content were observed followed by increases in the epoxide content late in the reaction. As this behavior was unexpected, too few data points were taken to map out the concentration as a function of reaction time. However, the greatest decrease observed in the epoxide concentration was about $40 \%$, and occurred after $6 \mathrm{hrs}$. This result suggests that at least a portion of any autoxidation products that might have formed could have undergone consecutive reactions to other products. The evidence is certainly not conclusive, however, as these products have not as 
yet been observed. The fact that the epoxide content began to climb late in the reactions suggests that whatever mechanism is responsible for the lack of autoxidation may be deactivated over time. As epoxides were not observed late in the initial experiments, it is possible that spiking the solutions enhanced this deactivation.

There are other possibilities to consider which may explain the lack of autoxidation products. For example, the catalyst may have been acting as an inhibitor by scavenging free radicals. This effect has been observed for high concentrations of homogenous autoxidation catalysts and is referred to as catalyst-inhibitor conversion [5]. There is little direct evidence for this effect in our work although relatively large amounts of catalyst were employed relative to homogeneous systems. A final possibility to consider is that peroxides in solution may be rendered unreactive by complexing with the HTOs. When dilute hydrogen peroxide is added to unexchanged HTOs, the material turns a bright yellow color from its usual white. A similar, although lighter, color is sometimes observed for the unexchanged HTO catalysts after they have been used in autoxidation experiments.

In conclusion, HTO based catalysts seem to be inappropriate choices for promoting autoxidation. In fact, they may inhibit autoxidation either through free radical scavenging or by reacting with peroxides. These possibilities should be explored, perhaps through the use of radical initiators such as benzoyl peroxide. There is some evidence, however, that the observed effects of HTO catalysts on autoxidation were due to further reactions of autoxidation products such as combustion or cracking. Further work is required to fully understand the results presented here.

\section{Selective Oxidation}

\section{A. Introduction}

The failure to achieve autoxidation with HTO based catalysts was not considered a severe setback since the generally poor selectivity of autoxidations renders them industrially unattractive. The exceptions to this rule are substrates that produce stable radical intermediates such as isobutane and cumene [6].

A wide range of catalysts are used industrially to selectively oxidize hydrocarbons. Many of these catalysts are homogenous metal complexes and the remainder are generally metal oxides or mixed metal oxides. Although excellent selectivity is often achieved with homogeneous catalysts, difficulties arise in separating the catalyst from the reaction mixture. For this reason, our initial work on selective oxidation catalysts was based on homogeneous catalyst systems. It was thought that metal ions exchanged onto the HMO supports might behave similarly to ions and complexes in solution, yet remain immobilized on the support for easy separation.

The metal oxide systems were considered to be more difficult to emulate with our system. The mixed metal oxide systems are generally thought to add oxygen to substrate molecules through the Mars-van Krevelen mechanism [7]. In this scenario, one cation in the crystal lattice binds with the substrate molecule and donates one of its oxygen atoms to the substrate. A second cation, generally a different metal, donates one of its oxygen atoms to replace the oxygen given up by the 
first cation, and then replenishes itself by reacting with molecular oxygen. The crystal lattice itself therefore acts as a reservoir for shuttling oxygen atoms. High temperatures are thus generally required for these catalysts in order to raise the mobility of oxygen through the lattice. As the HMO supports are amorphous, they may not contain the structure necessary for oxygen transport. Further doubts are raised by the fact that several of the selective oxidation reactions catalyzed by metal oxides are known to be structure sensitive [8]. In addition, the energetics of the oxygen binding are very important for the metal oxide systems. If oxygen is bound to the lattice too weakly, excessive combustion of the substrate occurs. If oxygen is bound too strongly, no transfer of oxygen occurs at all [8]. It is not known whether the HMOs possess an appropriate affinity for oxygen. However, the HMO supports do contain different cationic sites as found in active oxidation catalysts. Furthermore, the supports tend to become more structured as they are exposed to higher temperatures and start to dehydrate [18a-b]. The higher temperatures required to increase oxygen mobility in the system may also induce enough structure into the system for selective oxidation to occur.

The variable acidity of the HMOs may be an advantage for selective oxidation. For reactions in which a basic substrate is converted to an acidic compound, the conversion of propene to acrolein for example, an acidic catalyst would aid in the adsorption of the reactant and desorption of the product perhaps preventing excessive combustion. It follows that for reactions in which a basic reactant is converted into another basic compound, butene into butadiene for example, a moderately acidic or bifunctional catalyst might be appropriate. Likewise, the conversion of an acidic compound into a more basic one, ethyl benzene into styrene for example, might best be carried out on a basic catalyst $[9]$.

\section{B. Epoxidation}

A highly desirable industrial reaction is the epoxidation of olefins, for example the formation of ethylene oxide from ethylene or propylene oxide from propylene. The epoxidation of ethylene is generally carried out with oxygen over a silver based catalyst. This same catalyst however leads to combustion of olefins containing allylic hydrogen atoms such as propylene [10]. Although highly sought, a selective catalyst for the direct air epoxidation of olefins other than ethylene has not been developed. Therefore these olefins must be epoxidized through chlorohydrin processes or processes utilizing peroxides as oxidizing agents. Unfortunately, the chlorohydrin process suffers from the use of corrosive agents and the production of byproducts, including chlorinated byproducts [11]. Various peroxides can be used to epoxidize olefins including percarboxylic acids, hydrogen peroxide, or hydroperoxides such as t-butyl hydroperoxide [12]. Although these reagents give highly selective epoxidations, they have disadvantages associated with their use. For example $\mathrm{H}_{2} \mathrm{O}_{2}$ is fairly expensive while processes which utilize percarboxylic acids include several separation and purification steps in addition to regeneration steps which use $\mathrm{H}_{2} \mathrm{O}_{2}$. The use of other peroxides results in the production of a stoichiometric amount of coproduct. This greatly complicates and may compromise the overall economics of the process.

Typical homogeneous catalysts for epoxidation of olefins using hydroperoxides include $\mathrm{Mo}, \mathrm{V}, \mathrm{Ti}$ and $\mathrm{W}$ complexes [13]. Shell has developed a heterogeneous titania on silica catalyst [14], and Anic/Enichem has developed a zeolitic titanium-silicate, TS-1, which catalyzes the epoxidation of 
olefins with hydroperoxides [15] These heterogeneous catalysts can be thought of as immobilized redox metal ions.

The similarity between the heterogeneous Shell catalyst and TS-1 to Sandia's HMO and crystalline titanates is obvious. Therefore a crystalline silico-titanate and an amorphous catalyst containing silicon and titanium were screened for activity by adding $1 \mathrm{ml}$ of $3 \% \mathrm{H}_{2} \mathrm{O}_{2}$ and $2 \mathrm{ml}$ of 1 -octene to a reactor containing $100 \mathrm{mg}$ of catalyst (Table II). No oxidation products were obtained from this mixture. Instead, almost no hydrocarbon was recovered from the reactor. Similar results were obtained for other acidified catalysts in the presence of water. These results are discussed below in the section IV C.

Two approaches were taken in this work to screen other catalysts for epoxidation. The first was to take advantage of the fact that the most selective homogeneous catalysts are thought to react as peroxometal or metal-alkyl hydroperoxide species [2], and the reactive peroxometal species can sometimes be isolated and then used as stoichiometric oxidants [16].

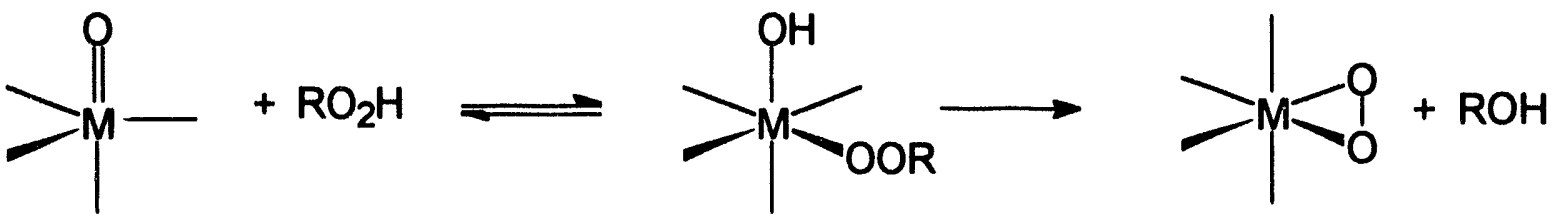



Therefore, potential catalysts were treated with $\mathrm{H}_{2} \mathrm{O}_{2}$ solutions which were then filtered off prior to their addition to the reactor in an attempt to form reactive peroxometal species. The second approach was to test catalysts for the ability to alter autoxidation profiles. This approach capitalizes on the fact that hydroperoxides are intermediates in autoxidation (see above) and therefore product distributions may be effectively altered by efficient epoxidation catalysts [17].

As molybdenum complexes have been successfully commercially employed as epoxidation catalysts [2,6] and generally have the highest rates and selectivities to epoxides [14], molybdenum was ion exchanged onto HTO supports for testing. Molybdenum also seemed an obvious choice in light of Sandia's extensive experience with HTO based molybdenum catalysts [18a]. 
Testing of the Mo catalysts was carried out as described in the experimental section above. The experiments and the results are summarized in Table III. Neither sodium (a small amount of $\mathrm{Na}$ probably remains in the catalyst even though the Mo was loaded under acidic conditions [18a]) nor protonated (acidified) versions of HTO loaded with Mo showed any evidence of promoting or altering oxidation reactions of 1 -octene after heating at $90^{\circ} \mathrm{C}$ for $5 \mathrm{hr}$. Considering the results for the autoxidation presented above, this is not surprising. Likewise, no oxidation reactions were observed over the catalysts that had been pretreated with $\mathrm{H}_{2} \mathrm{O}_{2}$. The pretreated catalysts were a bright yellow color while the as prepared catalysts were white indicating some reaction between the catalyst and the peroxide. A few experiments were carried out by adding several $\mathrm{ml}$ of $3 \%$ $\mathrm{H}_{2} \mathrm{O}_{2}$ directly to the reaction mixture. Again, no oxidation products, including diols, which would form if water hydrolyzed an epoxide, were observed. The exception was for an acidified catalyst that produced a trace of 2-octanol (see section IV C below). Some isomerization of the 1 -octene to internal olefins was observed for the each of the reactions carried out in the presence of an acidified Mo catalyst. This observation led to further experimentation that will be discussed in section IV $\mathrm{C}$ below.

As none of the Mo catalysts showed any obvious promise, and since several very selective catalysts already exist for converting olefins to epoxides using peroxides as reagents, these reactions were not pursued further. The use of ion exchanged HMOs as catalysts for reactions between olefins and peroxides was not conclusively ruled out; and it might be instructive to test some of these catalysts in the presence of high concentrations of $\mathrm{H}_{2} \mathrm{O}_{2}$ or an organic peroxide. However, it was thought to be more valuable to pursue novel routes to epoxides; particularly those which could directly utilize molecular oxygen as the oxidant. Few catalyst systems of this type have been reported.

One such system is based on the $\mathrm{Ru}$ (III) aquo ion, $\left[\mathrm{RuCl}_{2}\left(\mathrm{H}_{2} \mathrm{O}\right)_{4}\right]^{+}$, at $\mathrm{pH} 2.0$ in a mixed waterethanol or water-dioxane solvent [19]. Salts are added to maintain the ionic strength of the solution. In the case of ethanol, the solvent also acts as a reductant as acetaldehyde is observed as a coproduct. Several related systems have also been reported [20]. We tried to carry out similar chemistry by loading $\mathrm{RuCl}_{3}$ on crystalline silico-titanate (DG59) supports and then acidifying them to $\mathrm{pH} 1$ with $\mathrm{H}_{2} \mathrm{SO}_{4}$. Experiments were rarried out with these catalysts and 1-octene, and solutions of 1-octene with ethanol, and with ethanol and water. An experiment was also carried out on a two phase system consisting of 1-octene and water. Reactions were generally carried out at temperatures at or near the boiling points of the solutions.

The experiments and results for the Ru catalysts are summarized in Table IV. Epoxidation of the octene was not observed in any case. However, isomerization of the 1-octene to internal olefins was observed in almost every case. This isomerization proceeded at a rate about an order of magnitude greater than that observed for acidified catalysts with no metal loading. The isomerization also appeared to be more selective to the 2-octenes in the presence of $\mathrm{Ru}$ suggesting that the $\mathrm{Ru}$ was interacting with the olefin. In a few cases, there appeared to be evidence of autoxidation (traces of a large number of products) although the main product was identified as 3-octanone by GC-MS. This product could have arisen from the catalytic oxidation of 2-octene formed in the isomerization reaction. However, the absence of 2-octanone suggests this is unlikely since ketonization is generally more rapid for terminal olefins than for internal 
olefins [21]. After calcining the catalyst at $250^{\circ} \mathrm{C}$, autoxidation was observed, with a product distribution very similar to that observed during the autoxidation experiments described above. This result is consistent with the results obtained for other catalysts that utilized crystalline supports (see section III).

When ethanol was added to the reaction mixture, 1,1 diethoxyethane was formed. This acetal likely formed from the consecutive acid catalyzed reaction of ethanol with acetaldehyde formed from the ethanol [22].

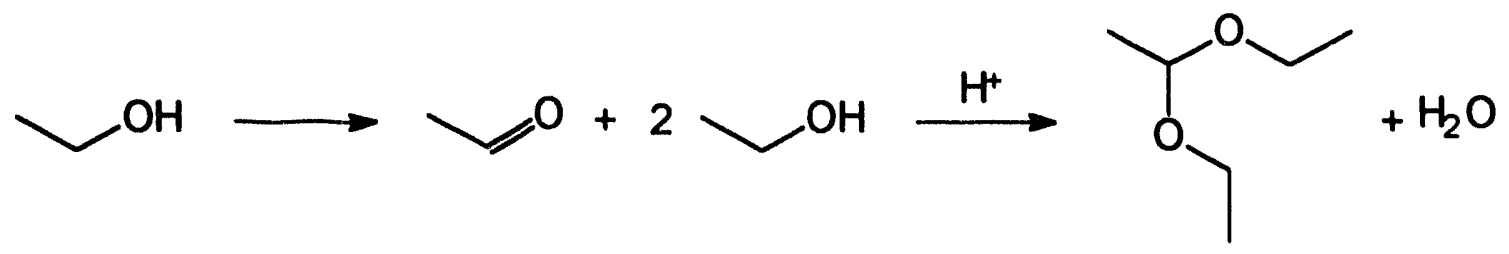

To test this hypothesis, a reaction was carried out on 1-octanol with the acidified Ru catalyst. Indeed, octanal was produced. However, only a small amount was formed before the reaction stopped. A similar effect had been seen for ethanol. Acidified DG59 with no metal loaded did not produce the acetal from ethanol under similar conditions. These results suggest that the reaction may have been stoichiometric and resulted from the reduction of the Ru(III) to a lower oxidation state. Although ethanol was proposed in the literature to act as a reducing agent [19], it was presumed to be converting $\mathrm{Ru}(\mathrm{V})$, formed in the initial reactions between the complex, oxygen, and olefin, to $\mathrm{Ru}(\mathrm{III})$. If the reactions of alcohols observed in our system were indeed due to the stoichiometric reduction of $\mathrm{Ru}(\mathrm{III})$, it would imply that the Ru in our system was not reacting with oxygen.

An interesting result was observed for the system containing 1-octene, ethanol, and water. After running the reaction at $70^{\circ} \mathrm{C}$ for $6 \mathrm{hrs}$, almost no octene was detected in the solution. This may have arisen from cracking reactions that produced products too volatile to be contained in the system by the condensers. This will be discussed below in section IV C concerning acidic catalysts.

There are some important differences between the literature systems and ours that should be noted. The substrates used in the literature systems were generally cyclic olefins or other olefins containing electron donating groups such as styrene or stilbene. Such compounds are known to be more easily epoxidized than $\alpha$-olefins by more traditional routes such as reactions with percarboxylic acids [12]. The only example of this general type of Ru catalyst system oxidizing an $\alpha$-olefin yielded a methyl ketone [23]. However, the particular system cited used a nitrosyl/nitro couple as a ligand to mediate the oxygen transfer and the results may not be indicative of other Ru catalysts. Another important point was that we acidified the catalyst with $\mathrm{H}_{2} \mathrm{SO}_{4}$. $\mathrm{HCl}$ might have been a more appropriate choice as this was used to prepare solutions of the $\left[\mathrm{RuCl}_{2}\left(\mathrm{H}_{2} \mathrm{O}\right)_{4}\right]^{+}$homogeneous catalysts. Furthermore, we did not add salts to the system to provide ionic strength to the solutions. Taking care to emulate the homogeneous systems more closely may yield improved results.

\section{Reactions with Acidic Catalysts}


As discussed above, when working with catalysts that had been acid treated, isomerization of 1-octene was consistently observed. The products were generally internal olefins although another product, tentatively identified as 1-ethylcyclohexene, was also commonly observed. Isomerization of olefins is known to occur through a carbocation mechanism in acidic solutions [22].

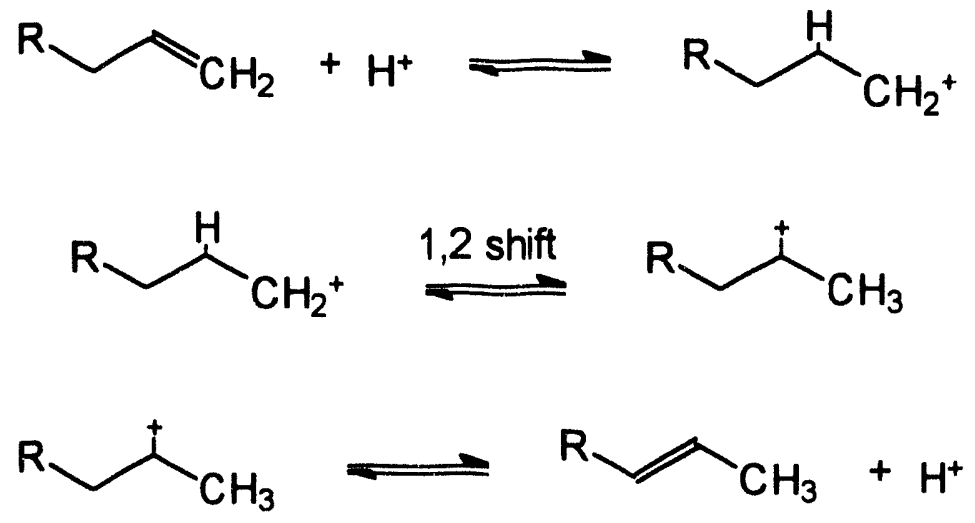

In order to relate the activity to the acid treatment, acidified forms of HMOs were compared directly to the $\mathrm{Na}$ forms of the HMO from which they were derived (Table V, first 4 entries). No metal loading was used. Isomerization was only observed for the acidified forms. These reactions are therefore directly the result of acidifying the HMO and are indicative of Bronsted acid sites.

Acids are known to catalyze the hydration of olefins to alcohols through carbocation mechanisms similar to those which lead to double bond isomerization [22].



This reaction is primarily useful for those molecules such as propene or isobutene that lead to a single stable carbocation and thus a single product. Solid acids can be used to promote these reactions. For example, highly acidic cation exchange resins have been used as catalysts to promote the hydration of propene to isopropyl alcohol [24], and to promote the hydration of 2-methyl butene to tert-amyl alcohol [25]. It was therefore decided to test the ability of the acidified HMO materials to promote the direct hydration of olefins. Recall that a two phase system consisting of $3 \% \mathrm{H}_{2} \mathrm{O}_{2}, 1$-octene and an acidified Mo HTO catalyst yielded a trace of 2-octanol (see section IV B above). For this reason acidified Mo catalysts were also tested. For 
ease and consistency 1-octene was again chosen as the substrate. A mixture of secondary alcohols was the expected product.

The experiment was first carried out with separate aqueous and organic phases. A single phase system that utilized ethanol as a solvent was also tested. The results of the hydration experiments are collected in Table $\mathrm{V}$. The results were somewhat surprising. When the reaction was carried out as a two phase system, not only was there an absence of alcohol formation, but the organic layer nearly entirely vanished. Likewise, when the single phase system was used, the 1-octene concentration was observed to steadily decline relative to the ethanol concentration. Recall that a similar result was obtained using the Ru catalyst system (section IV B), and using acidified titanates in the presence of $\mathrm{H}_{2} \mathrm{O}_{2}$ (Table II).

The unexpected disappearance, of 1-octene during the hydration and other experiments can be explained by examining other reactions that proceed through carbocations. In particular, cracking reactions are catalyzed by solid acids, and the reactions are known to involve cationic intermediates [26].

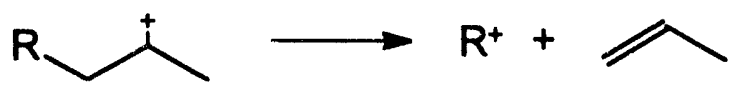

The apparent cyclization of 1-octene to 1-ethylcyclohexene observed over our acidified catalysts is a typical side reaction of olefins over cracking catalysts [26]. It is possible therefore that the disappearance of 1-octene from our system resulted from cracking reactions that produced gaseous products $\left(\mathrm{C}_{4}\right.$ or smaller) that were not retained by the system condensers. Although the reaction temperatures were somewhat lower than those typically employed for cracking, the residence time was much greater. Also, olefins crack at much higher rates than other hydrocarbons, as much as two orders of magnitude greater than the rates of paraffin cracking [27]. The effect we observed of water on the reaction is not understood. It is possible that water somehow alters the acidity of the catalyst, or helps the catalyst maintain activity for cracking reactions. Water has been recognized as an important cocatalyst for acid catalysis by zeolites [28]

There are other possible explanations for the disappearance of 1-octene from the reactors. The first is combustion type reactions as discussed for the autoxidation experiments. These seem unlikely since no intermediate oxygenates were observed. A more likely alternative explanation is that the olefin underwent cationic polymerization [22]. This explanation seems particularly appropriate for the cases involving ethanol. In those cases, the total amount of octene in the system was relatively small and the ethanol remained in the system as an organic solvent. Therefore, a residue from polymerization might not have been immediately obvious as it would have been for the other cases and could have escaped detection. 


\section{Ketonization}

Palladium is an important element for selective oxidation. Using $\mathrm{Pd}(\mathrm{II})$ catalysts, ethylene may be oxidized to at least 15 different products [6]. The most well known and widely practiced reaction of those 15 is the Wacker reaction, which converts ethylene to acetaldehyde. In this process $\mathrm{Pd}(\mathrm{II})$ is reduced to $\mathrm{Pd}(0)$ during the water oxidation of ethylene to acetaldehyde. To make the system catalytic, $\mathrm{Cu}(\mathrm{II})$ is added to reoxidize the $\mathrm{Pd}$ [29].

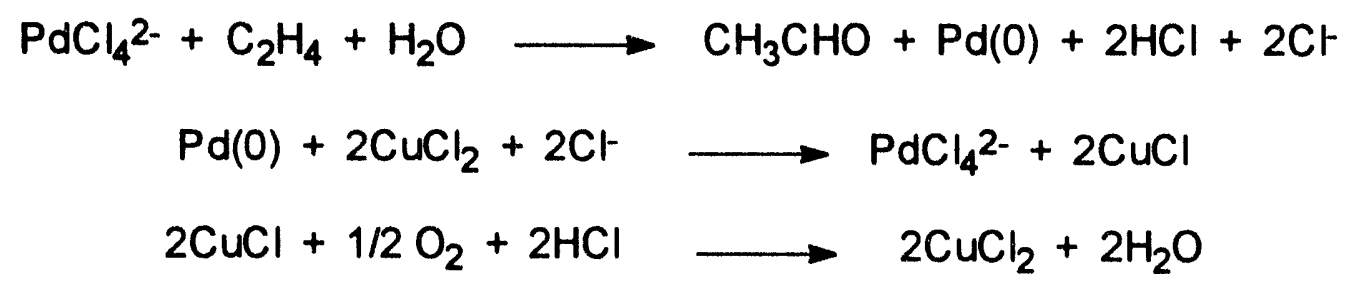

Higher olefins primarily produce ketones in the Wacker process [30]. For example, propylene reacts to form acetone.

There are some difficulties associated with the Wacker process. Chlorinated hydrocarbons are produced as byproducts. Furthermore, the aqueous palladium and copper chloride solutions employed lead to corrosion problems [27]. For olefins with more than 3 carbon atoms, other difficulties are encountered. The low solubility of the hydrocarbon in the aqueous solution leads to reduced reaction rates. Secondary oxidation of the ketone product is also a problem [31]. In addition, higher olefins are isomerized and mixtures of ketone products result [1]. Recently, some of these problems have been addressed by substituting heteropolyacids for $\mathrm{CuCl}_{2}$ in the system [32].

Wacker type reactions have been carried out over a number of palladium containing heterogeneous catalysts. These include $\mathrm{PdO}$ on alumina [33], $\mathrm{Pd}$ on alumina [34], $\mathrm{PdCl}_{2}$ on activated carbon [35], $\mathrm{Pd}(\mathrm{II})$ and $\mathrm{Cu}(\mathrm{II})$ exchanged zeolites [36], and $\mathrm{Pd}$ doped $\mathrm{V}_{2} \mathrm{O}_{5}$ [37]. However, the conventional Wacker process is still practiced commercially [38].

We carried out several experiments over Pd exchanged HTO catalysts. In light of the experience of others, these catalysts were expected to readily lead to ketonization of 1-octene. Other possible reactions were oxidation to a carboxylic acid [39] or oxidative dehydrogenation to a diene [40] or alkyne [41]. In none of the cases tested were any of the expected reactions observed. In independent tests, researchers at Shell obtained similarly poor results [42]. What we did observe at Sandia was extensive isomerization of the 1-octene substrate to internal olefins (Table VI). Cyclization to 1-ethylcyclohexene was also prominent. Consistent with the results for acidic catalysts described above, the hydrocarbon was lost when one of the reactions was carried cut in the presence of water (test 3). However a loss of hydrocarbon was also observed for a similar catalyst run for an extended period of time without the presence of water (test 5). Calcining one of the catalysts at $250^{\circ} \mathrm{C}$ increased the total amount of isomerization, but decreased the amount of cyclization (tests 1 and 2). Operating the reactor at lower temperatures slightly increased the amount of cyclization relative to the amount of isomerization (tests 4 and 6). 
The Pd catalysts seemed to rapidly deactivate. For example, after $1.25 \mathrm{hr}, 100 \mathrm{mg}$ of an acidified Pd catalyst had converted about $40 \%$ of a $2 \mathrm{ml}$ sample of 1 -octene to isomers. After an additional $3 \mathrm{hrs}$, only an additional $10 \%$ had been converted to isomers (test 1) even though the system was far from equilibrium. This could, however, be an effect of the decreasing 1-octene concentration. Additional experiments are required to be certain what caused the observed effect.

The isomerization and loss of hydrocarbon were probably once again the product of carbocation reactions. The loss of hydrocarbon in the two extended runs was probably the result of cracking reactions. In fact, preliminary tests with our catalysts in a closed system operating at $270^{\circ} \mathrm{C}$ yielded significant amounts of gaseous cracking products from both octane and 1-octene. Palladium loaded on acidic supports such as silica-alumina or zeolites is used industrially for hydrocracking [43, 44]. Consistent with our results, these catalysts are reported to promote isomerization and cyclizetion [44].

As palladium loaded HTOs did not seem to support the Wacker chemistry, other chemical systems with alternate reaction pathways were investigated. Catalyst systems capable of directly activating molecular oxygen were considered particularly attractive. It has been reported that certain $\mathrm{Rh}$ compounds, especially in the presence of alcohols and $\mathrm{Cu}$ compounds, can directly activate molecular oxygen to react with $\alpha$-olefins to produce methyl ketones with selectivities as high as $98 \%$ and little isomerization. A review of the literature [45-53] yields the following list of desirable components:

- Rh(III) species.

- $\mathrm{Cl}^{-}$- at least 3 mole/mole Rh. More promotes catalyst stability.

- $\mathrm{Cu}$ - about $2 \mathrm{~mole} / \mathrm{mole} \mathrm{Rh}$. More promotes alcohol oxidation.

- Bronsted acidity.

- Primary or secondary alcohol solvent, preferably ethanol or isopropanol.

The literature also indicates that, in contrast to the Wacker chemistry, water poisons the reaction. It is therefore desirable to suppress cooxidation of the solvent alcohol as water is a coproduct of this reaction.

Many roles have been proposed for copper in the active system. The first of these is playing a part in generating an active cationic $R h$ species [45, 46b, 48]. The second role proposed for copper is as a catalyst for the reduction of $\mathrm{O}_{2}$ to $\mathrm{H}_{2} \mathrm{O}_{2}[47,48] . \mathrm{H}_{2} \mathrm{O}_{2}$ may react with $\mathrm{Rh}$ to form the hydroperoxo $\mathrm{Rh}$ species which are thought to be intermediates in the olefin oxidation reaction $[48,50,52]$. Perhaps more importantly, $\mathrm{Cu}$ seems to play a role in promoting the transfer of the second atom of $\mathrm{O}_{2}$ to the olefin to form ketone $[45,48]$. In the absence of $\mathrm{Cu}$, at most only one oxygen atom per $\mathrm{O}_{2}$ reacts with the olefin to form ketone, while the other oxygen atom reacts with the alcohol to form an aldehyde or ketone and water. In the presence of $\mathrm{Cu}$ both oxygen atoms can be transferred to olefins. In this case the alcohol is only oxidized to a small extent at the beginning of the reaction, apparently in reactions that form the active $\mathrm{Rh}$ catalyst. The final role suggested for copper is inhibiting the isomerization of the 1-olefin substrate to internal olefins. This is necessary because $\mathrm{RhCl}_{3}$ is known as an olefin isomerization catalyst [54]. Since isomerization proceeds through $\mathrm{Rh}$ (III) hydrido complexes, it was suggested that $\mathrm{Rh}$ (III) hydrides may undergo rapid redox reactions with $\mathrm{Cu}(\mathrm{II})[48]$. 
The initial experiments conducted on Rh catalysts are summarized in Table VII. All the $\mathrm{Rh}$ catalysts used in this work were prepared from solutions of $\mathrm{Rh}\left(\mathrm{NO}_{3}\right)_{3}$. The catalysts were treated with acid to provide some Bronsted acidity to the system. The first experiments were conducted with acidified $\mathrm{Rh}$ catalysts alone (tests 1-3). A small amount of 2-octanone was produced from 1-octene by this catalyst (test 2). This positive result encouraged further testing.

The next step in the screening was to add other catalyst components to the system. It was decided for simplicity to initially test the effect of the additives by including them as homogeneous components in the system. Ethanol was used as a solvent to insure dissolution of the added salts and because it was indicated to be an important catalyst component. The experiments were carried out by weighing the HTO catalyst and salts into the reactor. The reactor was then heated under flowing $\mathrm{N}_{2}$ to temperatures greater than $125^{\circ} \mathrm{C}$ to dehydrate the salts as much as possible. The condenser was not connected to the reactor during this step. The reactor was then allowed to cool to below the desired reaction temperature before injecting the ethanol-1-octene solution. The solution typically contained 1:1 ethanol:1-octene by volume.

Adding ethanol alone to the reaction mixture containing the acidified $\mathrm{Rh}$ catalyst did not lead to 2-octanone formation although a portion of the ethanol reacted to form 1,1-diethoxyethane (test 3). The formation of the acetal likely resulted from the acid catalyzed reaction of acetaldehyde with ethanol as acetaldehyde is the likely product of ethanol oxidation. Since the vapor pressure of acetaldehyde is high enough that it could not be contained in the system by the condensers, no attempt was made to quantify the acetal concentration. Instead, in Table VII and subsequent tables, a simple comparison of the GC peak areas of acetal and 2-octanone is given for a relative comparison between experiments.

It was found that adding $\mathrm{Cu}$ in the form of $\mathrm{Cu}\left(\mathrm{NO}_{3}\right)_{2}$ to the ethanolic system led to extensive isomerization of the 1-octene along with a small amount of 2-octanone formation. The primary isomerization products in this and other experiments were the 2-octenes. Acetal was also formed (tests 4 and 5). Introducing $\mathrm{Cl}$ to the system as $\mathrm{LiCl}$ also led to isomerization, but no oxidation was observed (tests 6 and 7). A catalyst was prepared that contained $\mathrm{Cu}$ and $\mathrm{Rh}$ in a 2:1 mole ratio ion exchanged onto an HTO. It was not acidified to prevent the leaching of $\mathrm{Cu}$. This catalyst by itself proved to be completely inactive (test 8) and showed only minor amounts of isomerization in the presence of $\mathrm{LiCl}$ (test 9). The $\mathrm{Rh} \mathrm{HTO}$ was then tested in the presence of both $\mathrm{Cu}\left(\mathrm{NO}_{3}\right)_{2}$ and $\mathrm{LiCl}$ (tests 10-12). This combination produced small amounts of 2-octanone and some isomerization when run in the presence of $10 \% \mathrm{O}_{2} / \mathrm{N}_{2}$ (tests 10 and 11). However, when the same catalyst was run in ambient air (no gas flow into reactor) at $40^{\circ} \mathrm{C}$ (test 12 ), a significant increase in activity was observed (Figure 2).

The discovery that the oxygen concentration significantly influences the reaction conflicts with several reports that the rate for the homogeneous $\mathrm{Rh} / \mathrm{Cu}$ system is independent of the oxygen partial pressure $[45,48]$. However, there is at least one report on $\mathrm{Rh}$ catalysts without $\mathrm{Cu}$ additives that indicates that oxygen concentration does affect the reaction rate [46a]. Furthermore, another report indicates that at least one step in the conversion of the $\mathrm{Rh}(\mathrm{I})$ complex $\left[\mathrm{Rh}(\mathrm{CO})_{2} \mathrm{Cl}\right]_{2}$ to an active $\mathrm{Rh}(\mathrm{III})$ catalyst shows a first order dependence on oxygen 
concentration in the absence of $\mathrm{Cu}$ [47]. When this same $\mathrm{Rh}(\mathrm{I})$ complex is used as a catalyst without added $\mathrm{Cu}$, an induction period is observed whose length shows an inverse first order dependence on the oxygen concentration. Although our catalysts were prepared from $\mathrm{Rh}$ (III), an activation procedure may be responsible for the results observed in our system. This possibility is supported oy a number of tests which showed that flowing $10 \% \mathrm{O}_{2} / \mathrm{N}_{2}$ into the reactors after operating under ambient conditions for several hours did not hinder the further progress of the reaction. In any case all further studies were carried out under ambient conditions. Unlike experiments described in previous sections, all long term experiments were carried out continuously since at least some of the systems were active in ambient air at low temperatures.

It is significant that homogeneous $\mathrm{Rh} / \mathrm{Cu}$ catalysts show no dependence on oxygen concentration, while our catalysts and homogeneous $\mathrm{Rh}$ catalysts do show such a dependence. This may be an indication that supporting $\mathrm{Rh}$ on HTO hampers the interaction of $\mathrm{Rh}$ and $\mathrm{Cu}$. This possibility is also suggested by the large extent of isomerization observed in our system, $42 \%$ at $6.3 \%$ conversion, compared to the extent of isomerization reported in the literature, less than $5 \%$ at $50 \%$ conversion [45]. Another interesting result is that no oxidation products of octene other than 2-octanone were observed, despite the high concentration of internal olefins.

The next set of experiments that were undertaken is summarized in Table VIII. The first experiment verified the activity of the partially heterogeneous, partially homogeneous $\mathrm{Rh}$ $\mathrm{HTO} / \mathrm{Cu}\left(\mathrm{NO}_{3}\right)_{2} / \mathrm{LiCl} / \mathrm{EtCH}$ system. The reduced activity of the system compared to test 12 in Table VII probably was the result of a long purge of the reactor and its contents which was not performed in the original experiment. The next two experiments (tests 2 and 3 ) were performed to determine any effects of running the $\mathrm{Rh}$ only catalyst in ambient air. Similar tests were performed for the $\mathrm{Rh} / \mathrm{Cu}$ loaded $\mathrm{HTO}$ and the $\mathrm{Rh} \mathrm{HTO} / \mathrm{LiCl} / \mathrm{EtOH}$ systems (tests 4-7). The only noteworthy result was the production of 2-octanone by the Rh HTO/LiCl/EtOH system (test 7). However, as expected, this oxidation was accompanied by a large amount of isomerization and a significant amount of alcohol oxidation. The HTO loaded with both $\mathrm{Rh}$ and $\mathrm{Cu}$ gave 2-octanone in the presence of $\mathrm{LiCl}$ and ethanol (tests 8 and 9) and showed improvement over the $\mathrm{Rh}$ $\mathrm{HTO} / \mathrm{LiCl} / \mathrm{EtOH}$ system in the amount of isomerization, oxidation, and alcohol oxidation. However when compared to the $\mathrm{Rh} \mathrm{HTO} / \mathrm{Cu}\left(\mathrm{NO}_{3}\right)_{2} / \mathrm{LiCl} / \mathrm{EtOH}$ system the activity was much reduced (compare the lengths of the experiments), despite being run at a higher temperature, $70^{\circ} \mathrm{C}$ (Figure 3). An interesting result for the $\mathrm{Rh} / \mathrm{Cu} \mathrm{HTO} / \mathrm{LiCl} / \mathrm{EtOH}$ system was the unexpected appearance of two additional products. These products were detected in the early samples from the reactor, but not in the later samples suggesting that they may have been related to the formation of active Rh species. One of the products has been tentatively identified by GC-MS as the allylic ether 3-ethoxy-1-octene. There is a precedent in the literature for the formation of similar compounds from certain cyclic olefins using the homogeneous $\mathrm{Rh} / \mathrm{Cu}$ catalyst system [45].

The successful production of 2-octanone by the partially heterogeneous $\mathrm{Rh} / \mathrm{Cu} \mathrm{HTO} / \mathrm{LiCl} / \mathrm{EtOH}$ system led to an attempt to fully heterogenize the system. $\mathrm{Rh} / \mathrm{Cu}$ HTOs were prepared by fully exchanging the $\mathrm{Na}$ for $\mathrm{Cu}(\mathrm{II})$ and then back exchanging some of the $\mathrm{Cu}$ for $\mathrm{Rh}$ (III). These materials were then intimately mixed with $\mathrm{HCl}$ treated $(\mathrm{pH}=2.0)$ HTOs to provide Bronsted acidity and $\mathrm{Cl}^{-}$ion. The $\mathrm{Rh} / \mathrm{Cu} \mathrm{HTOs}$ were not acidified directly to prevent the exchange of $\mathrm{Cu}$ (II) for protons. A two level factorial design in three variables, HTO support, $\mathrm{Rh}: \mathrm{Cu}$ mole 
ratio, and ratio of acidified HTO to metal loaded HTO, was used to prepare a number of catalysts for testing. Some of each $\mathrm{Rh} / \mathrm{Cu} \mathrm{HTO}$ was reserved for testing without the added $\mathrm{HCl}$ treated material. Table IX summarizes the catalysts that were prepared according to the design, $\mathrm{CuRh} \mathrm{\# 1}$ - CuRh \#4-A-8, and their compositions assuming complete ion exchange for each step of the preparation. Two additional catalysts that will be discussed later are also shown in the table. Each of the tabulated catalysts was tested at $60^{\circ} \mathrm{C}$ in ambient air with a $1: 1 \mathrm{EtOH}: 1$-octene solution by volume. The tests were carried out over relatively lengthy periods due to their reduced activity compared to the more homogeneous systems.

The test results for the fully heterogeneous catalysts are presented in Table X. As expected, very little activity of any kind was observed for the catalysts with no acid content, $\mathrm{CuRh} \# \mathrm{l}-\mathrm{CuRh} \# 4$, despite being run for 48 continuous hrs. The results for catalysts CuRh \#1-A-1 - CuRh \#4-A-8, are presented in Table X. Similar to most of the previously described Rh experiments, 2-octanone was the only oxidation product observed to form from 1-octene. Also, ethanol was observed to oxidize continuously throughout the experiments. The information in Table $X$ is perhaps best understood through Figures 4-6. These figures present the three dependent variables specific rate, ratio of 1-ociene isomerization to 1 -octiene oxidation, and ratio of 2-octanone peak area to acetal peak area (see above) for each experiment on an xyz plot that indicates the catalyst composition. The specific rate reported in Table $X$ and Figure 4 is defined as the moles of 2-octanone formed per hr per mole of $\mathrm{Rh}$ in the system. As can be seen in Figures 4-6 the independent variable having the greatest effect on the dependent variables is the acid content of the catalyst, with the higher acid concentration giving the best results. Including Si in the hydrous titanate support also had a positive effect on the experimental outcome. Increasing the amount of $\mathrm{Cu}$ relative to the amount of $\mathrm{Rh}$ had little if any effect on the measured variables.

The decrease in isomerization and alcohol oxidation relative to 2-octanone formation for the catalysts with the high $\mathrm{HCl}$ content and the $\mathrm{Na}_{0.5} \mathrm{Ti}_{-}-\mathrm{Si}_{0.2}$ support appears to be mainly due to an increase in activity for 1-octene oxidation. That is, the overall amount of isomerization is still high as is the apparent amount of alcohol oxidation. Furthermore, acetal was observed to form continuously throughout each experiment. These observations coupled with the lack of influence of the $\mathrm{Rh}: \mathrm{Cu}$ ratio on the reaction again suggest that interactions between the $\mathrm{Rh}$ and $\mathrm{Cu}$ species are hindered by supporting them on HTOs.

Since the most positive effect on the catalyst was produced by high $\mathrm{HCl}$ content, two more catalysts were prepared for testing that contained even greater ratios of acid treated material to metal loaded HTO. Catalyst CuRh \#4-A-9 contained a 2:1 ratio of the two catalyst components and CuRh \#4-A-10 contained a 3:1 ratio of the two components (Table IX). Note that this material was prepared from $\mathrm{CuRh} \# 4$ which utilized the $\mathrm{Na}_{0.5} \mathrm{Ti}_{-} \mathrm{Si}_{0.2}$ support and a 1:1.5 $\mathrm{Rh}: \mathrm{Cu}$ ratio. The silicon containing support was chosen for its positive effect on the reaction, while the higher $\mathrm{Rh}: \mathrm{Cu}$ ratio was chosen simply because of the overall higher $\mathrm{Rh}$ content.

The reactions carried out in the presence of CuRh \#4-A-9 and CuRh \#4-A-10 are summarized in Table XI. Tests 1 and 2 were carried out to provide a direct comparison to the results presented in Table $\mathrm{X}$ for the catalysts containing lesser amounts of $\mathrm{HCl}$. Figures 7-9 provide a graphical comparison of the results. Clearly the "2:1" and "3:1" (CuRh \#4-A-9 and CuRh \#4-A-10) 
catalysts are superior to the "1:1" and "1:3" catalysts (CuRh \#4-A-7 and CuRh \#4-A-8). The "2:1" and "3:1" catalysts are more active (Figure 7), have a relatively low ratio of isomerization to oxidation (Figure 8), and oxidize relatively smaller amounts of alcohol (Figure 9). Since the " $2: 1$ " and " $3: 1$ " catalysts have the same specific rate, it appears that the maximum activity could be achieved with a ratio of acidified material to metal loaded material between $1: 1$ and $2: 1$. The best formulation however depends on the importance placed on isomerization and alcohol oxidation. Also the lifetime of the catalyst may be dependent on the $\mathrm{HCl}$ content.

The next set of tests was designed to determine the effect of temperature on the reaction. Experiments 3 and 4 utilized only $50 \mathrm{mg}$ of catalyst each due to the limited amount of the catalyst batch. It was clear from these tests that while raising the temperature from 60 to $70^{\circ} \mathrm{C}$ (the boiling point of the solution) increased the oxidation activity per $g$ of the catalysts, the larger effect was increasing the isomerization activity of the catalysts. The relative amount of alcohol oxidation also increased with temperature. Although there is a minimum amount of data, activation energies for isomerization and oxidation may be calculated from experiments 1-4 if the results are normalized to account for the amount of catalyst used. This calculation yields values of 26 and $6 \mathrm{kcal} / \mathrm{mole}$ for isomerization and oxidation respectively for CuRh \#4-A-9 and values of 22 and $10 \mathrm{kcal} / \mathrm{mole}$ for CuRh \#4-A-10. The fact that different amounts of catalysts were used for these experiments would only affect the calculation if the reactions were not first order in $\mathrm{Rh}$. The oxidation reaction has been reported to be first order in $\mathrm{Rh}$ for the homogeneous system [45, 48]; however, the literature suggests that the isomerization reaction may be $1 / 2$ order in $R h$ [55]. Adjusting the calculated values for this possibility gives activation energies for isomerization of 18 and $15 \mathrm{kcal} / \mathrm{mole}$ for $\mathrm{CuRh} \# 4-\mathrm{A}-9$ and $\mathrm{CuRh} \# 4-\mathrm{A}-10$ respectively.

Test 5 was an attempt to resolve this confusion. The $70^{\circ} \mathrm{C}$ experiment was repeated with $100 \mathrm{mg}$ of $\mathrm{CuRh} \# 4-\mathrm{A}-10$. Combining the results with those from test 2 gave an activation energy of 14 $\mathrm{kcal} / \mathrm{mole}$ for isomerization and an activation energy of $2 \mathrm{kcal} / \mathrm{mol}$ for oxidation suggesting that the isomerization is $1 / 2$ order in $\mathrm{Rh}$. In any case, one clear trend is that the calculated activation energies for oxidation are consistently less than $10 \mathrm{kcal} / \mathrm{mole}$. These low values strongly suggest that mass transfer and not kinetics was limiting the rate of the oxidation reaction [56]. This seems very plausible considering these experiments were run in ambient air with no gas flowing into the reactor to increase gas/liquid contact or stir the reactor contents. Therefore it is quite possible that better mixing of the system or operating at higher partial pressures of oxygen to increase the diffusional driving force may greatly improve the rate at which olefins are oxidized to ketones by this catalyst.

The final group of experiments performed with these catalysts was designed to elucidate the effect of ethanol and 1-octene concentration. Experiments were performed with mixtures that contained $1: 4$ and 4:1 parts of EtOH:1-octene by volume (tests 6-9). Figures 10 and 11 graphically present the results for $\mathrm{CuRh} \# 4-\mathrm{A}-10$. The results for $\mathrm{CuRh} \# 4-\mathrm{A}-9$ are similar (Table XI). Figure 10 indicates that the oxidation of 1-octene slows at high concentrations of 1-octene or ethanol. The results for the high ethanol concentration (low 1-octene concentration) were expected as the literature indicates a first order dependence on the olefin concentration for the reaction rate in the homogeneous system [45, 48]. The result for the high 1-octene concentration (low ethanol concentration) was unexpected as the literature indicates no dependence for the rate on ethanol 
concentration. The observed effect could again be related to poor interactions between $\mathrm{Rh}$ and $\mathrm{Cu}$ in the system. For example, if this interaction is poor or slow, the ethanol could play an important role in determining the reaction rate becaus? it may be needed to react with the second oxygen atom of oxygen molecules that have reacted with $\mathrm{Rh}$ species (see above). Recall that alcohol oxidation was observed to take place continuously in all these experiments. The isomerization reaction rate increased with 1-cctene concentration as expected (Figure 11). The literature indicates that olefin isomerization by certain $\mathrm{Rh}$ complexes is first order in olefin concentration [55]. The conclusion is that intermediate concentrations of ethanol and 1-octene lead to the highest oxidation activity and the mest favorable ratio of oxidation to isomerization.

There are several possibilities for improving the performance of the heterogeneous $\mathrm{Rh} / \mathrm{Cu}$ catalyst system. As discussed above, utilizing the catalyst in a system designed to promote rapid mass transport should at least increase the oxidation activity of the catalyst. This improvement also should increase the ratio of oxidation to isomerization. Regarding modifications to the catalyst

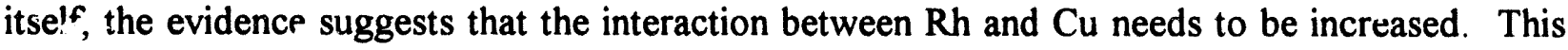
interaction probably suffers in the heterogeneous system because the hydrous titanium matrix restricts the mobility of the $\mathrm{Rh}$ and $\mathrm{Cu}$ ions. Similar problems probably limited the success of attempts of others to heterogenize the $\mathrm{PdCl}_{2} / \mathrm{CuCl}_{2}$ Wacker catalyst system [37]. One approach to overcoming this limitation would be to utilize very high ratios of $\mathrm{Cu}: \mathrm{Rh}$ in the system. Although the excess $\mathrm{Cu}$ might lead to greater amounts of alcohol oxidation, isomerization reactions might be suppressed by the increased likelihood of $\mathrm{Rh}$ species interacting with $\mathrm{Cu}$ species. A second approach would be to replace the HTO supports with crystalline titanate supports which had been doped with $\mathrm{Cu}$. Crystalline titanates have recently been prepared with various dopants included as part of the crystal lattice [57]. The use of $\mathrm{Cu}$ doped crystalline titanate supports might lead to the exchanged $\mathrm{Rh}$ ions being in closer proximity to $\mathrm{Cu}$ atoms. However, lattice $\mathrm{Cu}$ might not behave in the same manner as exchanged $\mathrm{Cu}$. For this reason, dopants other than $\mathrm{Cu}$ should be tested for the desired reactivity. This approach to the problem is similar to that of Evnin and coworkers [37] who created a heterogeneous Wacker catalyst by supporting $\mathrm{Pd}(\mathrm{II})$ and $\mathrm{V}_{2} \mathrm{O}_{5}$ on $\mathrm{Al}_{2} \mathrm{O}_{3}$. In this case, the $\mathrm{Pd}$ was able to interact more directly with the $\mathrm{V}_{2} \mathrm{O}_{5}$ than it could with supported $\mathrm{CuCl}_{2}$. The $\mathrm{V}_{2} \mathrm{O}_{5}$ was therefore able to keep the $\mathrm{Pd}(\mathrm{II})$ from being reduced to $\mathrm{Pd}(0)$ and thus becoming inactive while the $\mathrm{CuCl}_{2}$ was not. 


\section{References}

1. Sheldon, R. A.; Kochi, J. K. in Advances in Catalysis, Vol. 25 Eley, Pines, Weisz eds.; Academic Press: New York, 1976.

2. Lyons, J. E. in Applied Industrial Catalysis, Vol. 3 Leach ed.; Academic Press: New York, 1984.

3. For information on catalyst preparation techniques and on the shorthand notation used to describe various HMO catalysts see Dosch, R. G.; Stephens, H. P.; Stohl, F. V.; Bunker, B. C.; Peden, C. H. F. Hydrous Metal Oxide-Supported Catalysts: Part I. Preparation Chemistry and Chemical Properties, SAND89-2399, Albuquerque: Sandia National Laboratories, February 1990; and Stephens, H. P.; Dosch, R. G. in Preparation of Catalysts IV, Delmon, Grange, Jacoibs, and Poncelet eds.; Elsevier: Amsterdam, 1987, and Stephens, H. P.; Dosch, R. G.; Stohl, F. V. Ind. Eng. Chem. Prod. Res. Dev. 1985, $24,15$.

4. See for example Copping, C.; Uri, N. Discuss. Faraday Soc. 1968, 46, 202.

5. See for example Betts, A. T.; Uri, N. Adv. Chem. Ser. 1967, 76, 160.

6. Catalytica Ass. Multiclient Study No. 1077 Selective Oxidation of Hydrocarbons: $A$ Critical Analysis Catalytica Ass.: Santa Clara Ca., 1979.

7. Dadyburjor, D. B.; Jewur, S. S.; Ruckenstein, E. Catal. Rev. Sci. Eng. 1979, 19, 293.

8. Kung, H. H. Ind. Eng. Chem. Prod. Res. Dev. 1986, 25, 171.

9. See for example references 7 , and 8 .

10. Landau, R.; Brown, D.; Russell, J. L.; Kollar, J. Proc. 7th World Petroleum Congress Mexico City, 1967.

11. Liu, G. Y. T.; Richey, F.; Betso, J. E. in Ullman's Encyclopedia of Industrial Chemistry, Vol. A6, Fifth ed.; Weinheim: New York, 1987.

12. Sienel, G.; Rieth, R. in Ullman's Encyclopedia of Industrial Chemistry, Vol. A9, Fifth ed.; Weinheim: New York, 1987.

13. Lyons, J. E. Hydrocarbon Processing 1980, November 107. Also see references 1,2, 6, and 12 .

14. Sheldon, R. A.; Van Doorn, J. A. J. Catal. 1973, 31, 427. and references therein.

15. Sheldon, R. A. Chemtech 1991, September, 566. 
16. Mimoun, H.; Seree de Roch, I.; Sasjus, L Tetrahedron 1970、 26, 37.

17. See for example Arzoumanian, H.; Blanc, A.; Hartig, U.; Metzger, J. Tetrahedron Lett. 1974, 12, 1011 ., and Fusi, A.; Ugo, R.; Zanderighi, G. M. J. Catal 1974, 34, 175.

18. a) Dosch, R. G.; Stephens, H. P.; Stohl, F. V.; Bunker, B. C.; Peden, C. H. F. Hydrous Metal Oxide-Supported Catalysts: Part I. Preparation Chemistry and Chemical Properties, SAND89-2399, Albuquerque: Sandia National Laboratories, February 1990; and Dosch, R. G.; Stephens, H. P.; Stohl, F. V. Hydrous Metal Oxide-Supported Catalysts: Part II. Catalytic Properties and Applications, Sand89-2400, Albuquerque: Sandia National Laboratories, February 1990. b) Gardner, T. J.; Peden, C. H. F.; Datye, A. K. Catal. Lett. 1992, 15, 111; and Anderson, S. L.; Datye, A. K.; Braunschweig, E. J.; Peden, C. H. F. Appl. Catal. A 1992, 82, 185.

19. Khan, M. M. T.; Rao, A. P.; Shukla, R. S. J. Mol. Catal. 1989, 49, 299.; and Khan, M. M. T.; Rao, A. P.; Bhatt, S. D.; Merchant, R. R. J. Mol. Catal. 1990, 62, 265.

20. Khan, M. M. T.; Mirza, S. A.; Bajaj, H. C. J. Mol. Catal. 1987, 42, 323.; Khan, M. M. T.; Shukla R. S. J. Mol. Catal. 1988, 44, 85.; Khan, M. M. T.; Bajaj, H. C.; Shukla, R. S.; Mirza, S. A. J. Mol. Catal. 1988, 45, 51.; Khan, M. M. T.; Chatterjee, D.; Shirin, Z.; Bajaj, H. C.; Siddiqui, M. R. H.; Venkatasubramanian, K.; Bhadbhade, M. M. J. Mol. Catal. 1992, 72, 271.; and Khan, M. M. T.; Shukla, R. S. J. Mol. Catal. 1992, 72, 361.

21. See for example Stern, E. W. Catal Rev. 1967, 1, 73.; Henry, P. M. J. Am. Chem. Soc. 1966, 88, 1595.; Fujimoto, K.; Takeda, H.; Kunugi, T. Ind. Eng. Chem., Prod. Res. Develop. 1974, 13, 237.; Arai, H.; Yamashiro, T.; Kubo, T.; Tominago, H. Bull. Jap. Petrol. Inst. 1976, 18, 39.; and Mimoun, H.; Machirant, M. M. P.; Seree de Roch, I. J. Am. Chem. Soc. 1978, 100, 5437.

22. Streitwieser, A.; Heathcock, C. H. Introduction to Organic Chemistry, Second Ed.; Macmillan: New York, 1981.

23. Khan, M. M. T.; Chatterjee, D.; Shirin, Z.; Bajaj, H. C.; Siddiqui, M. R. H.; Venkatasubramanian, K.; Bhadbhade, M. M. J. Mol. Catal. 1992, 72, 271.

24. Neier, W.; Woellner, J. Chemtech 1973, February, 95.

25. Giles, J. H.; Stultz, J. H.; Jones, S. W. U. S. Patent 41829201980 to Dow Chemical Co.

26. Wojciechowski, B. W.; Corma, A. Catalytic Cracking: Catalysts, Chemistry, and Kinetics; Marcel Dekker: New York, 1986.

27. Gates, B. C.; Katzer, J. R.; Schuit, G. C. A. Chemistry of Catalytic Processes; McGraw-Hill: New York, 1979. 
28. Haag, W. O.; Chen, N. Y. in Catalyst Design: Progress and Perspectives Hegedus, ed.; Wiley \& Sons: New York, 1987.

29. Smidt, J.; Hafner, W.; Jira, R.; Sieber, R.; Sedlmeier, J.; Sabel, A. Angew. Chem. Int. Ed. Engl. 1962, 1, 80.

30. Stern, E. W. Catal Rev. 1967, $1,73$.

31. Faraj, M.; Martin, J.; Martin, C.; Bregeault, J.; Mercier, J. J. Mol. Catal. 1985, 31, 57.

32. Grate, J. H.; Hamm, D. R.; Mahajan, S. Preprint 14th Conference on Catalysis of Organic Reactions 1992, Albuquerque, NM.

33. Hirsch, L.; Hornig, K.; Hornig, T.; Hornig, L.; Mau, G.; Quadflieg, T. U. S. Patent 34196181968.

34. Hirsch, L.; Hornig, K.; Hornig, T.; Hornig, L.; Mau, G.; Quadflieg, T. U. S. Patent 34390441969.

35. Fujimoto, K.; Negami, Y.; Takahashi, T.; Kunugi, T. Ind. Eng. Chem. Prod. Res. Develop. 1972, 11, 303, and Fujimoto, K.; Takeda, H.; Kunugi, T. Ind. Eng. Chem. Prod. Res. Develop. 1974, 13, 237.

36. Arai, H.; Yamashiro, T.; Kubo, T.; Tominaga, H. Bull. Jap. Petrol. Inst. 1976, 18, 39.

37. Evnin, A. B.; Rabo, J. A.; Kasai, P. H. J. Catal. 1973, 30, 109.

38. Chemical \& Engineering News January 27, 1992, 31.

39. Hinnenkamp, J. A.; Scheben, J. A. U. S. Patent 41884901980.

40. Wagner, F. S. in Applied Industrial Catalysis, Vol. 2 Leach ed.; Academic Press: New York, 1984.

41. Cum, G.; Gallo, R.; Ipsale, S.; Spadaro, A. J. Chem Soc., Chem. Commun. 1985, 1571.

42. Tom Forschner, private communication.

43. Ward, J. W. in Applied Industrial Catalysis, Vol. 3 Leach ed.; Academic Press: New York, 1984.

44. Satterfield, C. N. Heterogeneous Catalysis in Practice; McGraw-Hill: New York, 1980.

45. Mimoun, H.; Machirant, M. M. P.; Seree de Roch, I. J. Am. Chem. Soc. 1978, $100,5437$. 
46. a) Dahlmann, J.; Hoft, E. Oxidation Comm. 1983, 5, 391 and b) 405.

47. Nyberg, E. D.; Pribich, D. C.; Drago, R. S. J. Am. Chem. Soc. 1983, 10` 3538.

48. Drago, R. S.; Zuzich, A.; Nyberg, E. D. J. Am. Chem. Soc. 1985, 107, 2898.

49. Bressan, M.; Morandini, I.; Rigo, P. J. Organometall. Chem. 1983, 247, C8.

50. Faraj, M.; Martin, J.; Martin, C.; Bregeault, J. M.; Mercier, J. J. Mol. Catal. 1985, 31, 57.

51. Bressan, M.; Morandini, F.; Morvillo, A.; Rigo, P. J. Organometall. Chem. 1985, 280, 139.

52. Martin, C.; Faraj, M.; Martin, J.; Bregeault, J. M.; Mercier, J.; Fillaux, J.; Dizabo, P. J. Mol. Catal. 1986, 37, 201.

53. El Ali, B.; Bregeault, J. M.; Martin, J. J. Organometall. Chem. 1987, 327, C9.

54. Parshall, G. W. Homogeneous Catalysis; Wiley \& Sons: New York, 1980.

55. Tuner, M.; v. Jouanne, J.; Brauer, H. D.; Kelm, H. J. Mol. Catal. 1979, 5, 425 and 433.

56. Froment, G. F.; Bischoff, K. B. Chemical Reactor Analysis and Design; Wiley \& Sons: New York, 1979.

57. R. G. Dosch, private communication. 
Table I. Summary of Autoxidation Experiments

\begin{tabular}{|c|c|c|c|c|}
\hline Catalyst & Pretreatment & $\begin{array}{l}\text { Rxn. Temp. } \\
\left({ }^{\circ} \mathrm{C}\right)\end{array}$ & $\begin{array}{c}\text { Rxn. Time } \\
\text { (hr) }\end{array}$ & Result \\
\hline No catalyst & N.A. & 110 & 6 & Autoxidation \\
\hline $\mathrm{Mn}\left(\mathrm{Na}_{0,5} \mathrm{~T}-\mathrm{Si}_{0.2}\right)$ & As Prepared & 100 & 6 & No Rxn. \\
\hline $\mathrm{Mn}\left(\mathrm{Na}_{0.5} \mathrm{~T}-\mathrm{Si}_{0.2}\right)$ & Calcined $500^{\circ} \mathrm{C}$ & $90-110$ & 12 & No Rxn. \\
\hline $\begin{array}{c}\operatorname{Min}(D G 61, \\
\text { SNLTAM5\#60) }\end{array}$ & As Prepared & 100 & 6 & No $R \times n$. \\
\hline $\begin{array}{c}\text { Mn(DG61, } \\
\text { SNLTAM5\#60) }\end{array}$ & $\begin{array}{c}\text { Calcined } 250, \\
500^{\circ} \mathrm{C} \\
\end{array}$ & 110 & $6-12$ & Autoxidation \\
\hline$\left(\mathrm{Na}_{0.5} \mathrm{~T}-\mathrm{Si}_{0.2}\right)$ & As Prepared & 110 & 6 & No Rxn. \\
\hline DG61 & As Prepared & 110 & 12 & No Rxn. \\
\hline DG61" & $\begin{array}{c}\text { Calcined } \\
275^{\circ} \mathrm{C}\end{array}$ & 110 & 9 & No $R \times n$. \\
\hline
\end{tabular}

* Crystalline silico-titanates.

Table II. Reactions of 1-Octene in Presence of Titanates and $\mathrm{H}_{2} \mathrm{O}_{2}$

\begin{tabular}{|c|c|c|c|c|}
\hline Catalyst & $\begin{array}{c}\text { Rxn. Mixture } \\
\text { (by volume) }\end{array}$ & $\begin{array}{c}\text { Rxn. Temp. } \\
\left({ }^{\circ} \mathrm{C}\right)\end{array}$ & $\begin{array}{c}\text { Rxn. Time } \\
(\mathrm{hr})\end{array}$ & Result \\
\hline $\mathrm{H}_{0.5} \mathrm{~T}^{\mathrm{S}} \mathrm{Si}_{0.2}$ & $\begin{array}{c}1: 2 \\
3 \% \mathrm{H}_{2} \mathrm{O}_{2}: 1 \text {-octene }\end{array}$ & 90 & 6 & $\begin{array}{c}\text { organic phase } \\
\text { disappears }\end{array}$ \\
\hline Acidified DG59 & $\begin{array}{c}1: 2 \\
3 \% \mathrm{H}_{2} \mathrm{O}_{2}: 1 \text {-octene }\end{array}$ & 90 & 6 & $\begin{array}{c}\text { organic phase } \\
\text { disappears }\end{array}$ \\
\hline
\end{tabular}


Table III. Summary of Experiments with Mo Catalysts

\begin{tabular}{|c|c|c|c|c|}
\hline Catalyst & Pretreatment & $\begin{array}{c}\text { Rxn. Temp. } \\
\left({ }^{\circ} \mathrm{C}\right)\end{array}$ & $\begin{array}{c}\text { Rxn. Time } \\
(\mathrm{hr})\end{array}$ & Result \\
\hline $\mathrm{Mo}\left(\mathrm{Na}_{0.5} \mathrm{Ti}\right)$ & None & 90 & 5 & No Rxn. \\
\hline $\mathrm{Mo}\left(\mathrm{H}_{0.5} \mathrm{Ti}\right)$ & $\mathrm{None}$ & 90 & 5 & Isomerization \\
\hline $\mathrm{Mo}\left(\mathrm{Na}_{0.5} \mathrm{Ti}\right)$ & $\mathrm{H}_{2} \mathrm{O}_{2}$ & $100-110$ & 6.5 & No Rxn. \\
\hline $\mathrm{Mo}\left(\mathrm{H}_{0 .} \mathrm{Ti}\right)$ & $\mathrm{H}_{2} \mathrm{O}_{2}$ & $100-110$ & 5.5 & Isomerization \\
\hline $\mathrm{Mo}\left(\mathrm{Na}_{0.5} \mathrm{Ti}\right)$ & $\mathrm{H}_{2} \mathrm{O}_{2}{ }^{*}$ & 90 & 5 & No Rxn. \\
\hline $\mathrm{Mo}\left(\mathrm{H}_{0.5}{ } \mathrm{Ti}\right)$ & $\mathrm{H}_{2} \mathrm{O}_{2}{ }^{*}$ & 90 & 5 & $\begin{array}{c}\text { Isomerization } \\
\text { 2-octanol }\end{array}$ \\
\hline
\end{tabular}

* Several $\mathrm{ml}$ of $3 \% \mathrm{H}_{2} \mathrm{O}_{2}$ added to reactor

Table IV. Summary of experiments with Ru Catalysts

\begin{tabular}{|c|c|c|c|c|}
\hline Catalyst & $\begin{array}{c}\text { Rxn. Mixture } \\
\text { (by volume) }\end{array}$ & $\begin{array}{l}\text { Rxn. Temp. } \\
\left({ }^{\circ} \mathrm{C}\right)\end{array}$ & $\begin{array}{l}\text { Rxn. Time } \\
\text { (hr) }\end{array}$ & Result \\
\hline $\begin{array}{c}\mathrm{RuCl}_{3} \text { (Acidified } \\
\text { DG59) } \\
\end{array}$ & 1-octene & 105 & 5 & $\begin{array}{c}\text { isomerization } \\
\text { 3-octanone }\end{array}$ \\
\hline Acidified DG59 & 1-octene & 105 & 5 & less isomerization \\
\hline $\begin{array}{c}\mathrm{RuCl}_{3} \text { (Acidified } \\
\text { DG59) }\end{array}$ & 1-octene & 70 & 5 & isomerization \\
\hline $\begin{array}{c}\mathrm{RuCl}_{3} \text { (Acidified } \\
\text { DG59) } \\
\text { calcined } 275^{\circ} \mathrm{C} \\
\end{array}$ & 1-octene & 110 & 9 & autoxidation \\
\hline $\begin{array}{c}\mathrm{RuCl}_{3} \text { (Acidified } \\
\text { DG59) }\end{array}$ & $\begin{array}{l}1: 4 \mathrm{H}_{2} \mathrm{O}: \\
1 \text {-octene }\end{array}$ & 90 & 5 & $\begin{array}{c}\text { isomerization } \\
\text { 3-octanone }\end{array}$ \\
\hline Acidified DG59 & $\begin{array}{l}1: 4 \mathrm{H}_{2} \mathrm{O}: \\
1 \text {-octene }\end{array}$ & 90 & 5 & less isomerization \\
\hline $\begin{array}{c}\mathrm{RuCl}_{3} \text { (Acidified } \\
\text { DG59) }\end{array}$ & $\begin{array}{l}\text { 1:1 EtOH: } \\
\text { 1-octene }\end{array}$ & 70 & 5.5 & $\begin{array}{c}\text { isomerization } \\
\text { acetal }\end{array}$ \\
\hline Acidified DG59 & $\begin{array}{l}\text { 1:1 EtOH: } \\
\text { 1-octene }\end{array}$ & 70 & 5.5 & No $R \times n$ \\
\hline $\begin{array}{c}\mathrm{RuCl}_{3} \text { (Acidified } \\
\text { DG59) } \\
\end{array}$ & 1-octanol & 110 & 5.5 & octanal \\
\hline $\begin{array}{c}\mathrm{RuCl}_{3} \text { (Acidified } \\
\text { DG59) }\end{array}$ & $\begin{array}{c}1: 2: 10 \\
\mathrm{H}_{2} 0: 1 \text {-octene:EtOH }\end{array}$ & 70 & 6 & $\begin{array}{l}\text { 1-octene content } \\
\text { declines }\end{array}$ \\
\hline
\end{tabular}


Table V. Summary of Reactions with Acid Catalysts and their Na Analogs

\begin{tabular}{|c|c|c|c|c|}
\hline Catalyst & $\begin{array}{c}\text { Rxn. Mixture } \\
\text { (by volume) }\end{array}$ & $\begin{array}{l}\text { Rxn. Temp. } \\
\left({ }^{\circ} \mathrm{C}\right)\end{array}$ & $\begin{array}{l}\text { Rxn. Time } \\
\text { (hr) }\end{array}$ & Result \\
\hline $\mathrm{Na}_{0.5} \mathrm{~T}$ & 1-octene & 110 & 7 & No $\mathrm{Rxn}$. \\
\hline $\mathrm{H}_{0.5} \mathrm{~T}$ & 1-octene & 110 & 7 & isomerization \\
\hline $\mathrm{Na}_{0} \mathrm{~T}-\mathrm{Si}_{02}$ & 1-octene & 110 & 7 & No Rxn. \\
\hline $\mathrm{H}_{0.5} \mathrm{~T}-\mathrm{Si}_{02}$ & 1-octene & 110 & 7 & isomerizáion \\
\hline $\mathrm{H}_{0.5} \mathrm{~T}$ & $\begin{array}{c}1: 4 \\
\mathrm{H}_{2} 0: 1 \text {-octene } \\
\end{array}$ & 90 & 7 & $\begin{array}{c}\text { organic phase } \\
\text { disappears }\end{array}$ \\
\hline$\overline{\mathrm{H}_{0.5}} \overline{\mathrm{T}-\mathrm{Si}_{0.2}}$ & $\begin{array}{c}1: 4 \\
\mathrm{H}_{2} 0: 1 \text {-octene } \\
\end{array}$ & 90 & 7 & $\begin{array}{l}\text { organic phase } \\
\text { disappears }\end{array}$ \\
\hline $\mathrm{Mo}\left(\mathrm{H}_{0.5} \mathrm{Ti}\right)$ & $\begin{array}{c}1: 4 \\
\mathrm{H}_{2} 0: 1 \text {-octene } \\
\end{array}$ & 90 & 7 & $\begin{array}{c}\text { organic phase } \\
\text { disappears }\end{array}$ \\
\hline $\begin{array}{c}\mathrm{Mo}\left(\mathrm{H}_{0,5} \mathrm{Ti}\right) \\
\mathrm{H}_{2} \mathrm{O}_{2} \text { pretreated }\end{array}$ & $\begin{array}{c}1: 4 \\
\mathrm{H}_{2} 0: 1 \text {-octene } \\
\end{array}$ & 90 & 7 & $\begin{array}{c}\text { organic phase } \\
\text { disappears }\end{array}$ \\
\hline $\mathrm{H}_{0.5} \mathrm{~T}$ & $\begin{array}{c}1: 2: 10 \\
\mathrm{H}_{2} 0: 1 \text {-octene:EtOH } \\
\end{array}$ & 75 & 14 & $\begin{array}{c}1 \text {-octene content } \\
\text { declines }\end{array}$ \\
\hline $\mathrm{H}_{0.5} \mathrm{~T}-\mathrm{Si}_{0.2}$ & $\begin{array}{c}1: 2: 10 \\
\mathrm{H}_{2} 0: 1 \text {-octene:EtOH } \\
\end{array}$ & 75 & 14 & $\begin{array}{c}\text { 1-octene content } \\
\text { declines }\end{array}$ \\
\hline $\mathrm{Mo}\left(\mathrm{H}_{0.5} \mathrm{Ti}\right)$ & $\begin{array}{c}1: 2: 10 \\
\mathrm{H}_{2} 0: 1 \text {-octene:EtOH }\end{array}$ & 75 & 14 & $\begin{array}{c}\text { 1-octene content } \\
\text { declines }\end{array}$ \\
\hline $\begin{array}{c}\mathrm{Mo}\left(\mathrm{H}_{0.5} \mathrm{Ti}\right) \\
\mathrm{H}_{2} \mathrm{O}_{2} \text { pretreated }\end{array}$ & $\begin{array}{c}1: 2: 10 \\
\mathrm{H}_{2} 0: 1 \text {-octene:EtOH }\end{array}$ & 75 & 14 & $\begin{array}{c}\text { 1-octene content } \\
\text { declines }\end{array}$ \\
\hline
\end{tabular}

* Volume Ratios 
Table VI. Summary of Experiments with Pd Catalysts

\begin{tabular}{|c|c|c|c|c|c|}
\hline \multirow{2}{*}{ Test } & \multirow{2}{*}{ Catalyst } & \multirow{2}{*}{$\begin{array}{l}\text { Rxn. Temp. } \\
\quad\left({ }^{\circ} \mathrm{C}\right)\end{array}$} & \multirow{2}{*}{$\begin{array}{l}\text { Rxn. Time } \\
\text { (hr) }\end{array}$} & \multicolumn{2}{|c|}{$\%$ Conversion to Products } \\
\hline & & & & Isomers & Cyclic \\
\hline 1 & $\mathrm{Pd}\left(\mathrm{H}_{0,5} \mathrm{~T}-\mathrm{Si}_{02}\right)$ & 110 & 4.5 & 52 & 1.3 \\
\hline 2 & $\begin{array}{l}\mathrm{Pd}\left(\mathrm{H}_{0.5} \mathrm{~T}-\mathrm{Si}_{0.2}\right) \\
\text { calcined } 250^{\circ} \mathrm{C}\end{array}$ & 110 & 4.5 & 65 & .2 \\
\hline 3 & $\begin{array}{l}\mathrm{Pd}\left(\mathrm{H}_{0.5} \mathrm{~T}-\mathrm{Si}_{0.2}\right) \\
\text { calcined } 250^{\circ} \mathrm{C} \text { a }\end{array}$ & 95 & 14.5 & \multicolumn{2}{|c|}{ organic phase disappeared } \\
\hline 4 & $\mathrm{Pd}\left(\mathrm{H}_{0.5} \mathrm{Ti}\right)$ & 110 & 4.25 & 50 & 1.3 \\
\hline 5 & $\mathrm{Pd}\left(\mathrm{H}_{0.5} \mathrm{Ti}\right)^{\mathrm{b}}$ & $75-110$ & 16 & \multicolumn{2}{|c|}{ no organic remains } \\
\hline 6 & $\mathrm{Pd}\left(\mathrm{H}_{0.5} \mathrm{Ti}\right)$ & $70-85$ & 7.25 & 29 & 1.0 \\
\hline
\end{tabular}

a $1 \mathrm{ml}$ of 1-octene added to reactor. b $50 \mathrm{mg}$ additional catalyst added after first $4.25 \mathrm{hr}$. Temperature rose as hydrocarbon was depleted. 
Table VII. Summary of Experiments with Rh Catalysts Under $10 \% \mathrm{O}_{2} / \mathrm{N}_{2}$

\begin{tabular}{|c|c|c|c|c|c|c|c|}
\hline \multirow[b]{2}{*}{ Test } & \multirow[b]{2}{*}{ Catalyst } & \multirow{2}{*}{$\begin{array}{l}\text { Rxn. Mixture } \\
\text { (vol. ratios) }\end{array}$} & \multirow{2}{*}{$\begin{array}{l}\text { Rxn. Temp. } \\
\left({ }^{\circ} \mathrm{C}\right)\end{array}$} & \multirow{2}{*}{$\begin{array}{l}\text { Rxn. Time } \\
\text { (hr) }\end{array}$} & \multicolumn{2}{|c|}{$\%$ Conversion to Products ${ }^{\mathrm{a}}$} & \multirow{2}{*}{$\begin{array}{c}\text { 2-octanone: } \\
\text { Acetal } \\
\text { area ratio }^{\mathrm{b}}\end{array}$} \\
\hline & & & & & Isomers & 2-octanone & \\
\hline 1 & $\mathrm{Rh}\left(\mathrm{H}_{0,5} \mathrm{~T}\right)$ & 1-octene & 110 & 4.25 & 23 & 0 & - \\
\hline 2 & $\mathrm{Rh}\left(\mathrm{H}_{0.5} \mathrm{~T}\right)$ & 1-octene & $65-83$ & 8.25 & 37 & 0.4 & - \\
\hline 3 & $\mathrm{Rh}\left(\mathrm{H}_{0.5} \mathrm{~T}\right) 50 \mathrm{mg}$ & $\begin{array}{c}1: 1 \\
\text { EtOH: } 1 \text {-octene }\end{array}$ & 70 & 7.5 & 21 & 0 & $\begin{array}{c}\text { trace of } \\
\text { acetal }\end{array}$ \\
\hline 4 & $\begin{array}{l}\mathrm{Rh}\left(\mathrm{H}_{0.5} \mathrm{~T}\right) 50 \mathrm{mg} \\
\mathrm{Cu}\left(\mathrm{NO}_{3}\right)_{2} 20 \mathrm{mg}\end{array}$ & $\begin{array}{c}1: 1 \\
\text { EtOH:1-octene }\end{array}$ & 70 & 4 & 85 & 0.5 & 0.9 \\
\hline 5 & $\begin{array}{l}\mathrm{Rh}\left(\mathrm{H}_{0.5} \mathrm{~T}\right) 50 \mathrm{mg} \\
\mathrm{Cu}\left(\mathrm{NO}_{3}\right)_{2} 20 \mathrm{mg}\end{array}$ & $\begin{array}{c}1: 1 \\
\text { EtOH:1-octene }\end{array}$ & 40 & 3.5 & 38 & 0.4 & $\begin{array}{l}\text { trace of } \\
\text { acetal }\end{array}$ \\
\hline 6 & $\begin{array}{c}\mathrm{Rh}\left(\mathrm{H}_{0.5} \mathrm{~T}\right) 50 \mathrm{mg} \\
\mathrm{LiCl} 20 \mathrm{mg}\end{array}$ & $\begin{array}{c}1: 1 \\
\text { EtOH:1-octene }\end{array}$ & 70 & 3 & 60 & - & - \\
\hline 7 & $\begin{array}{c}\mathrm{Rh}\left(\mathrm{H}_{0.5} \mathrm{~T}\right) 50 \mathrm{mg} \\
\mathrm{LiCl} 20 \mathrm{mg}\end{array}$ & $\begin{array}{c}1: 1 \\
\text { EtOH:1-octene }\end{array}$ & 55 & 3 & 28 & - & - \\
\hline 8 & $\mathrm{Rh} / \mathrm{Cu}\left(\mathrm{Na}_{0.5} \mathrm{~T}^{\mathrm{T}}\right)^{\mathrm{c}}$ & $\begin{array}{c}1: 1 \\
\text { EtOH:1-octene }\end{array}$ & 70 & 5.5 & No $R \times n$. & - & - \\
\hline 9 & $\begin{array}{c}\mathrm{Rh} / \mathrm{Cu}\left(\mathrm{Na}_{0.5} \mathrm{~T}\right)^{\mathrm{C}} \\
\mathrm{LiCl} 20 \mathrm{mg}\end{array}$ & $\begin{array}{c}1: 1 \\
\text { EtOH:1-octene }\end{array}$ & 40 & 4.5 & 6 & - & - \\
\hline 10 & $\begin{array}{c}\mathrm{Rh}\left(\mathrm{H}_{0.5} \mathrm{~T}\right) 50 \mathrm{mg} \\
\mathrm{Cu}\left(\mathrm{NO}_{3}\right)_{2} 20 \mathrm{mg} \\
\mathrm{LiCl} 20 \mathrm{mg}\end{array}$ & $\begin{array}{c}1: 1 \\
\text { EtOH:1-octene }\end{array}$ & $50-70$ & 7.5 & 13 & 0.6 & trace of acetal \\
\hline 11 & $\begin{array}{c}\mathrm{Rh}\left(\mathrm{H}_{0.5} \mathrm{~T}\right) 50 \mathrm{mg} \\
\mathrm{Cu}\left(\mathrm{NO}_{3}\right)_{2} 20 \mathrm{mg} \\
\mathrm{LiCl} 20 \mathrm{mg}\end{array}$ & $\begin{array}{c}1: 1 \\
\text { EtOH:1-octene }\end{array}$ & 40 & 8.5 & 18 & 0.3 & $\begin{array}{l}\text { no acetal } \\
\text { observed }\end{array}$ \\
\hline $12^{\mathrm{d}}$ & $\begin{array}{c}\mathrm{Rh}\left(\mathrm{H}_{0.5} \mathrm{~T}\right) 50 \mathrm{mg} \\
\mathrm{Cu}\left(\mathrm{NO}_{3}\right)_{2} 20 \mathrm{mg} \\
\mathrm{LiCl} 20 \mathrm{mg}\end{array}$ & $\begin{array}{c}1: 1 \\
\text { EtOH:1-octene }\end{array}$ & 40 & 3.5 & 42 & 6.3 & trace of acetal \\
\hline
\end{tabular}

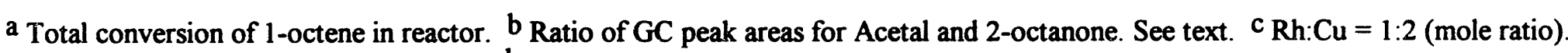
d This experiment was carried out under ambient air. 
Table VII. Summary of Experiments with Rh Catalysts in Ambient Air

\begin{tabular}{|c|c|c|c|c|c|c|c|}
\hline \multirow[b]{2}{*}{ Test } & \multirow[b]{2}{*}{ Catalyst } & \multirow{2}{*}{$\begin{array}{l}\text { Rxn. Mixture } \\
\text { (vol. ratios) }\end{array}$} & \multirow{2}{*}{$\begin{array}{l}\text { Rxn. Temp. } \\
\left({ }^{\circ} \mathrm{C}\right)\end{array}$} & \multirow{2}{*}{$\begin{array}{c}\text { Rxn. Time } \\
\text { (hr) }\end{array}$} & \multicolumn{2}{|c|}{$\%$ Conversion to Products ${ }^{a}$} & \multirow{2}{*}{$\begin{array}{c}\text { 2-octanone: } \\
\text { Acetal } \\
\text { area ratio }^{b}\end{array}$} \\
\hline & & & & & Isomers & 2-octanone & \\
\hline 1 & $\begin{array}{c}\mathrm{Rh}\left(\mathrm{H}_{0.5} \mathrm{~T}\right) 50 \mathrm{mg} \\
\mathrm{Cu}\left(\mathrm{NO}_{3}\right)_{2} 20 \mathrm{mg} \\
\mathrm{LiCl} 20 \mathrm{mg}\end{array}$ & $\begin{array}{c}1: 1 \\
\text { EtOH:1-octene }\end{array}$ & 40 & 4.5 & 20 & 1.0 & trace of acetal \\
\hline 2 & $\mathrm{Rh}\left(\mathrm{H}_{0.5} \mathrm{~T}\right) 50 \mathrm{mg}$ & 1-octene & $60-70$ & 5 & 1.5 & - & - \\
\hline 3 & $\mathrm{Rh}\left(\mathrm{H}_{0.5} \mathrm{~T}\right) 50 \mathrm{mg}$ & $\begin{array}{c}1: 1 \\
\text { EtOH:1-octene }\end{array}$ & $60-70$ & 5 & 14 & - & trace of acetal \\
\hline 4 & $\begin{array}{c}\mathrm{Rh} / \mathrm{Cu}\left(\mathrm{Na}_{0.5} \mathrm{~T}\right)^{\mathrm{C}} \\
50 \mathrm{mg}\end{array}$ & 1-octene & $60-70$ & 5 & No Rxn. & - & - \\
\hline 5 & $\begin{array}{c}\mathrm{Rh} / \mathrm{Cu}\left(\mathrm{Na}_{0.5} \mathrm{~T}\right)^{\mathrm{C}} \\
50 \mathrm{mg}\end{array}$ & $\begin{array}{c}1: 1 \\
\text { EtOH:1-octene }\end{array}$ & $60-70$ & 5 & No $\mathrm{Rxn}$. & - & \\
\hline 6 & $\begin{array}{c}\mathrm{Rh}\left(\mathrm{H}_{0.5} \mathrm{~T}\right) 50 \mathrm{mg} \\
\mathrm{LiCl} 10 \mathrm{mg}\end{array}$ & 1-octene & 70 & 23.5 & 21 & - & - \\
\hline 7 & $\begin{array}{c}\mathrm{Rh}\left(\mathrm{H}_{0.5} \mathrm{~T}\right) 50 \mathrm{mg} \\
\mathrm{LiCl} 10 \mathrm{mg}\end{array}$ & $\begin{array}{c}1: 1 \\
\text { EtOH:1-octene }\end{array}$ & 70 & 23.5 & 35 & 1.5 & 0.5 \\
\hline 8 & $\begin{array}{c}\mathrm{Rh} / \mathrm{Cu}\left(\mathrm{Na}_{0.5} \mathrm{~T}\right)^{\mathrm{c}} \\
50 \mathrm{mg} \\
\mathrm{LiCl} 10 \mathrm{mg}\end{array}$ & 1-octene & 70 & 23.5 & 1.0 & - & - \\
\hline 9 & $\begin{array}{c}\mathrm{Rh} / \mathrm{Cu}\left(\mathrm{Na}_{0.5} \mathrm{~T}\right)^{\mathrm{c}} \\
50 \mathrm{mg} \\
\mathrm{LiCl} 10 \mathrm{mg}\end{array}$ & $\begin{array}{c}1: 1 \\
\text { EtOH:1-octene }\end{array}$ & 70 & 23.5 & 17 & 2.5 & 8.5 \\
\hline
\end{tabular}

a Total conversion of 1-octene in reactor. ${ }^{b}$ Ratio of $G C$ peak areas for Acetal and 2-octanone. See text. ${ }^{c} \mathrm{Rh}: \mathrm{Cu}=1: 2$ (mole ratio). 
Table IX. Calculated Composition of Fully Heterogeneous CuRh Catalysts

\begin{tabular}{|c|c|c|c|c|c|}
\hline \multirow[b]{2}{*}{ Catalyst } & \multirow[b]{2}{*}{ Support ${ }^{\mathrm{a}}$} & \multicolumn{2}{|c|}{ Weight Loading } & \multirow{2}{*}{$\begin{array}{c}\mathrm{Rh}: \mathrm{Cu} \\
\text { Mole ratio }\end{array}$} & \multirow{2}{*}{$\begin{array}{c}\text { Acidified: } \\
\text { CuRh loaded }\end{array}$} \\
\hline & & $\% \mathrm{Cu}$ & $\% \mathrm{Rh}$ & & \\
\hline CuRh \#1 & $\mathrm{Na}_{0.5} \mathrm{~T}$ & 7.4 & 4.1 & $1: 2.9$ & - \\
\hline CuRh \#2 & $\mathrm{Na}_{0} 5 \mathrm{~T}$ & 5.7 & 6.0 & $1: 1.5$ & - \\
\hline CuRh \#3 & $\mathrm{Na}_{0,5} \mathrm{~T}-\mathrm{Si}_{0.2}$ & 6.3 & 3.3 & $1: 3.0$ & - \\
\hline CuRh \#4 & $\mathrm{Na}_{0.5} \mathrm{~T}-\mathrm{Si}_{02}$ & 4.7 & 5.2 & $1: 1.5$ & - \\
\hline $\mathrm{CuRh} \# 1-\mathrm{A}-1$ & $\mathrm{Na}_{0.5} \mathrm{~T}$ & 5.6 & 3.1 & $1: 2.9$ & $1: 3$ \\
\hline CuRh \#1-A-2 & $\mathrm{Na}_{0.5} \mathrm{~T}$ & 3.7 & 2.1 & $1: 2.9$ & $1: 1$ \\
\hline $\mathrm{CuRh} \# 2-\mathrm{A}-3$ & $\mathrm{Na}_{0.5} \mathrm{~T}$ & 4.3 & 4.5 & $1: 1.5$ & $1: 3$ \\
\hline CuRh \#2-A-4 & $\mathrm{Na}_{0,5} \mathrm{~T}$ & 2.9 & 3.0 & $1: 1.5$ & $1: 1$ \\
\hline CuRh \#3-A-5 & $\mathrm{Na}_{0.5} \mathrm{~T}-\mathrm{Si}_{02}$ & 4.7 & 2.5 & $1: 3.0$ & $1: 3$ \\
\hline CuRh \#3-A-6 & $\mathrm{Na}_{0.5} \mathrm{~T}-\mathrm{Si}_{0.2}$ & 3.2 & 1.7 & $1: 3.0$ & $1: 1$ \\
\hline CuRh \#4-A-7 & $\mathrm{Na}_{0.5} \mathrm{~T}-\mathrm{Si}_{02}$ & 3.5 & 3.9 & $1: 1.5$ & $1: 3$ \\
\hline $\mathrm{CuRh} \# 4-\mathrm{A}-8$ & $\mathrm{Na}_{0.5} \mathrm{~T}-\mathrm{Si}_{0.2}$ & 2.4 & 2.6 & $1: 1.5$ & $1: 1$ \\
\hline CuRh \#4-A-9 & $\mathrm{Na}_{0}{ }_{5} \mathrm{~T}-\mathrm{Si}_{02}$ & 1.6 & 1.7 & $1: 1.5$ & $2: 1$ \\
\hline CuRh \#4-A-10 & $\mathrm{Na}_{0.5} \mathrm{~T}-\mathrm{Si}_{02}$ & 1.2 & 1.3 & $1: 1.5$ & $3: 1$ \\
\hline
\end{tabular}

a Catalysts were prepared so that the $\mathrm{Na}$ ions should have been fully exchanged for $\mathrm{Cu}$ and $\mathrm{Rh}$. $\mathrm{b}$ Weight ratio of support material treated with $\mathrm{HCl}$ at $\mathrm{pH} 2.0$ and $\mathrm{CuRh}$ loaded material mixed together to form final catalyst. 
Table X. Summary of Experiments with Fully Heterogeneous CuRh Catalysts - Ambient Air Conditions



a See Table IX for catalyst composition $\mathrm{b}$ Total conversion of 1-octene in reactor. ${ }^{c}$ Ratio of GC peak areas for Acetal and 2-octanone. See text. d Moles of 2-octanone per total moles of $R h$ in catalyst per hour. 
Table XI. Summary of Reactions With CuRh \#4-A-9 and CuRh \#4-A-10




2-octanone. See text. d Moles of 2-octanone per total moles of $\mathrm{Rh}$ in catalyst per hour. 


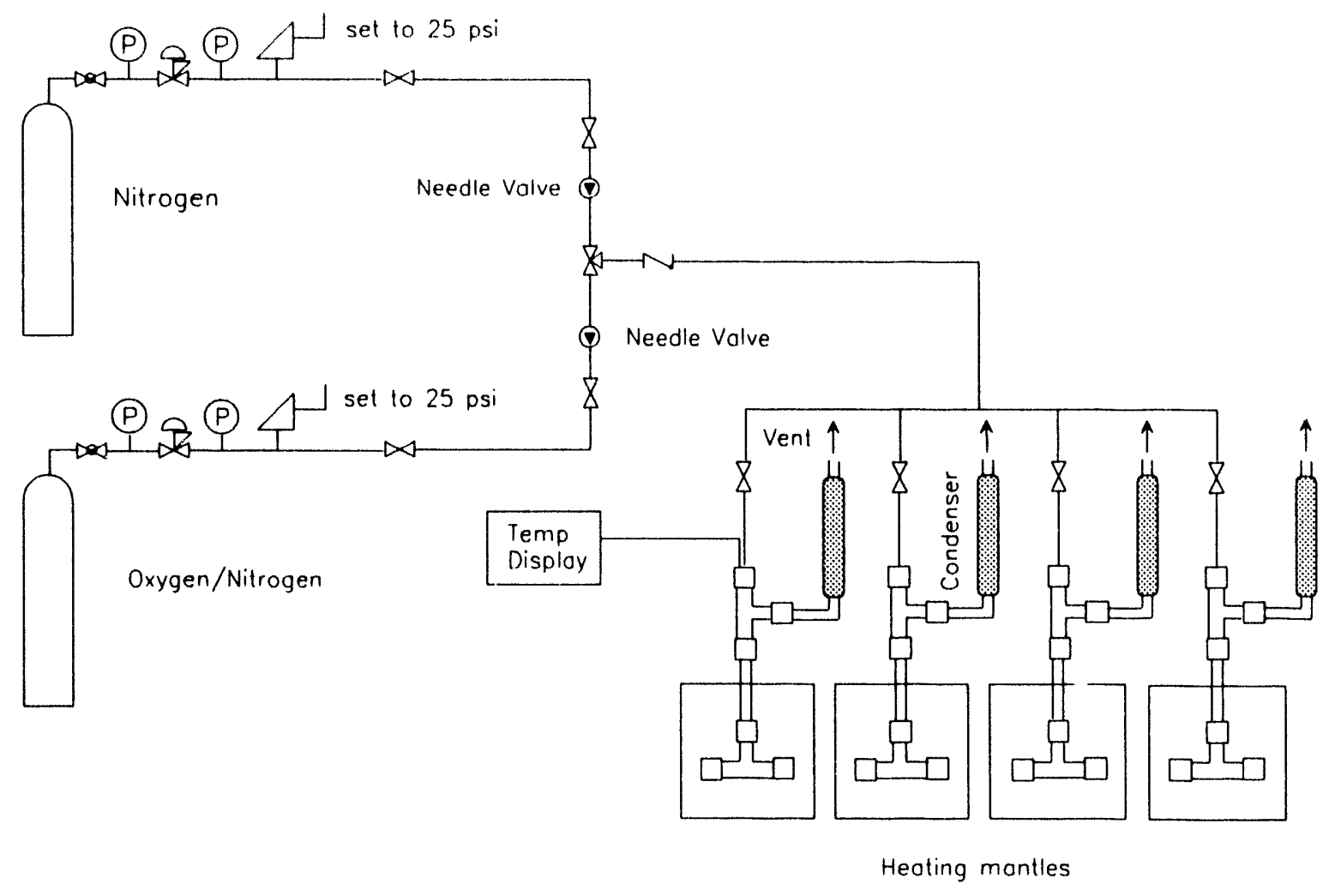

Figure 1. Apparatus for screening oxidation catalysts 


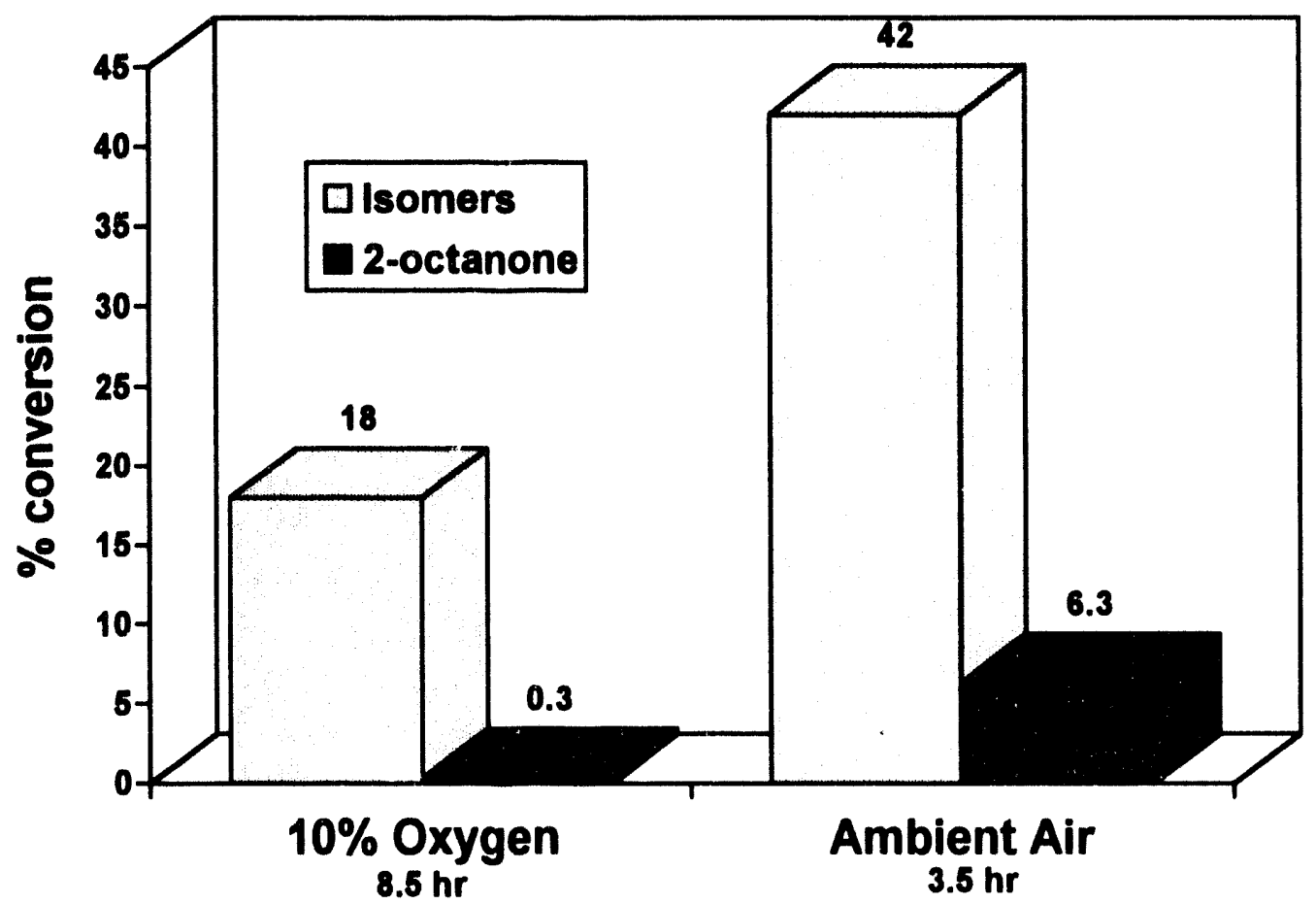

Figure 2. Conversion of 1 -octene to products with $\mathrm{Rh} \mathrm{HTO} / \mathrm{Cu}\left(\mathrm{NO}_{3}\right)_{2} / \mathrm{LiCl}$ catalyst system. The reactions were carried out at $40^{\circ} \mathrm{C}$ with a $1: 1 \mathrm{EtOH}: 1$-octene solution by volume. The oxygen source was flowing $10 \% \mathrm{O}_{2}$ in $\mathrm{N}_{2}$ or ambient air. 


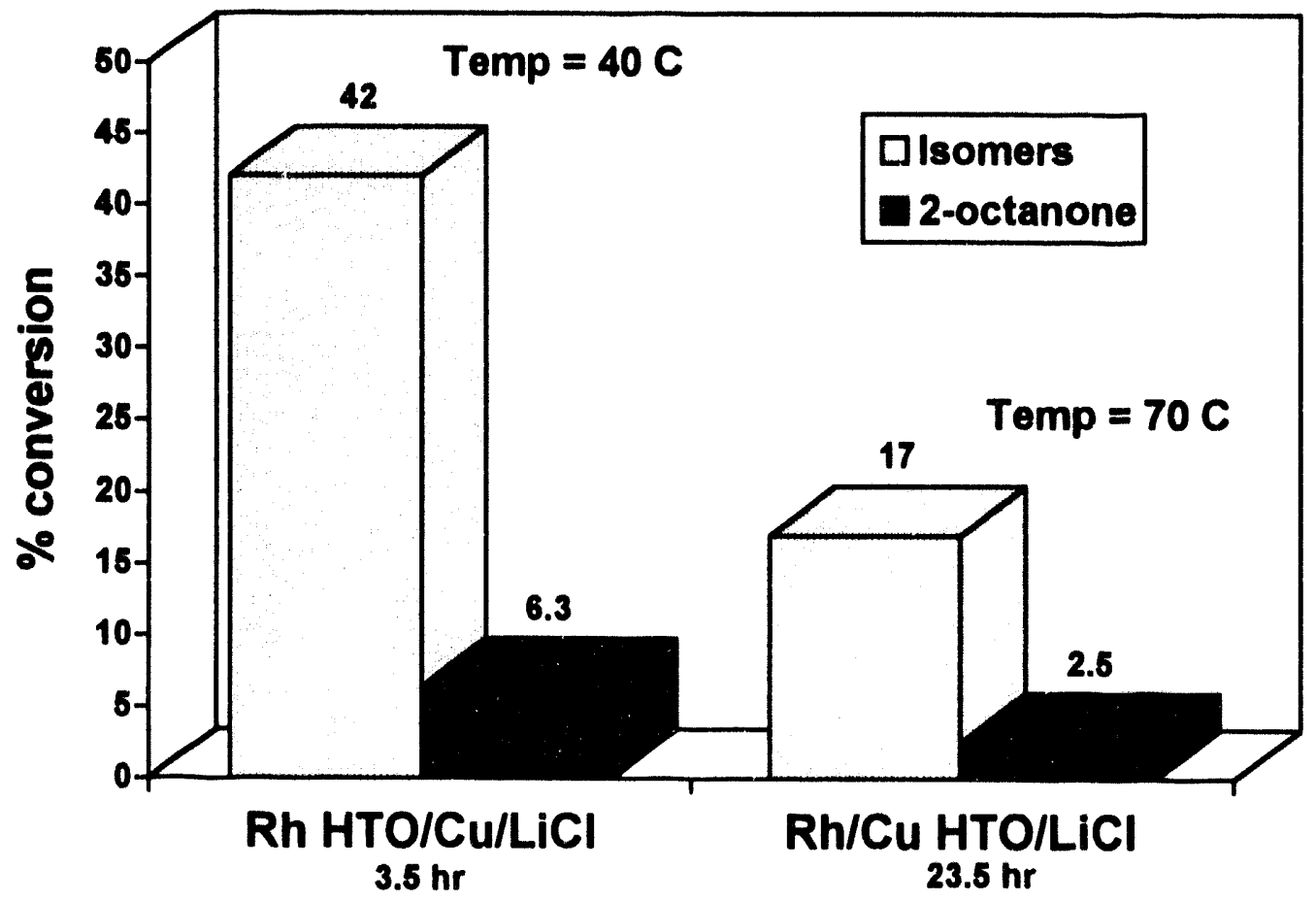

Figure 3. Comparison of the $\mathrm{Rh} \mathrm{HTO} / \mathrm{Cu}\left(\mathrm{NO}_{3}\right)_{2} / \mathrm{LiCl}$ catalyst system to the more heterogeneous $\mathrm{Rh} / \mathrm{Cu} \mathrm{HTO} / \mathrm{LiCl}$ catalyst system. Experiments were performed at the indicated temperatures for the indicated times with a 1:1 EtOH:1-octene solution by volume under ambient air. 


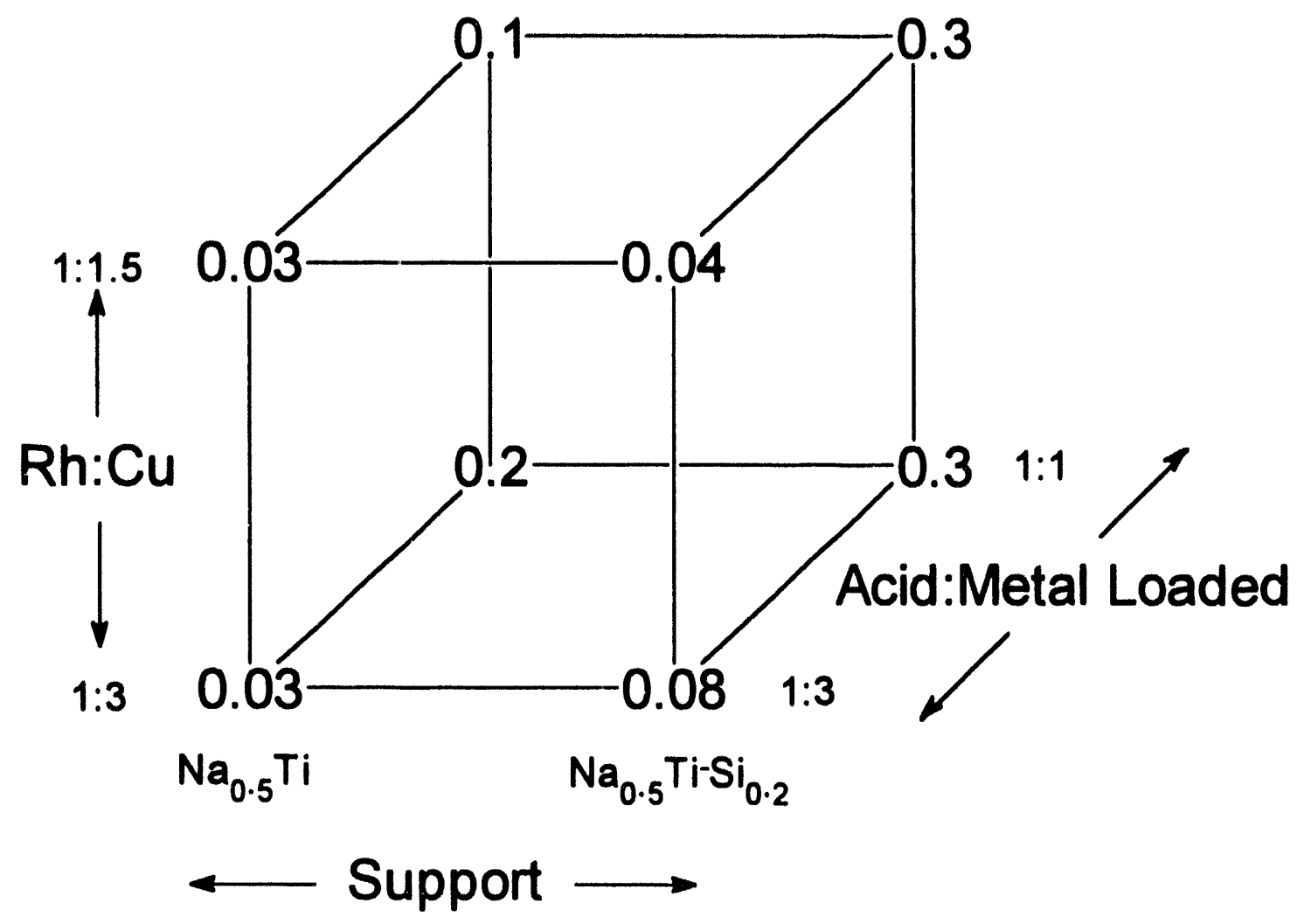

Figure 4. Specific rate as a function of catalyst composition (see Table IX.) for the fully heterogeneous catalysts CuRh \#1-A-1 - CuRh \#4-A-8. Specific rate is defined as moles of 2-octanone formed per hr per mole of $R h$ in the system. 




Figure 5. Ratio of isomerization to oxidation of 1-octene as a function of catalyst composition (see Table IX.) for the fully heterogeneous catalysts CuRh \#1-A-1 - CuRh \#4-A-8. 


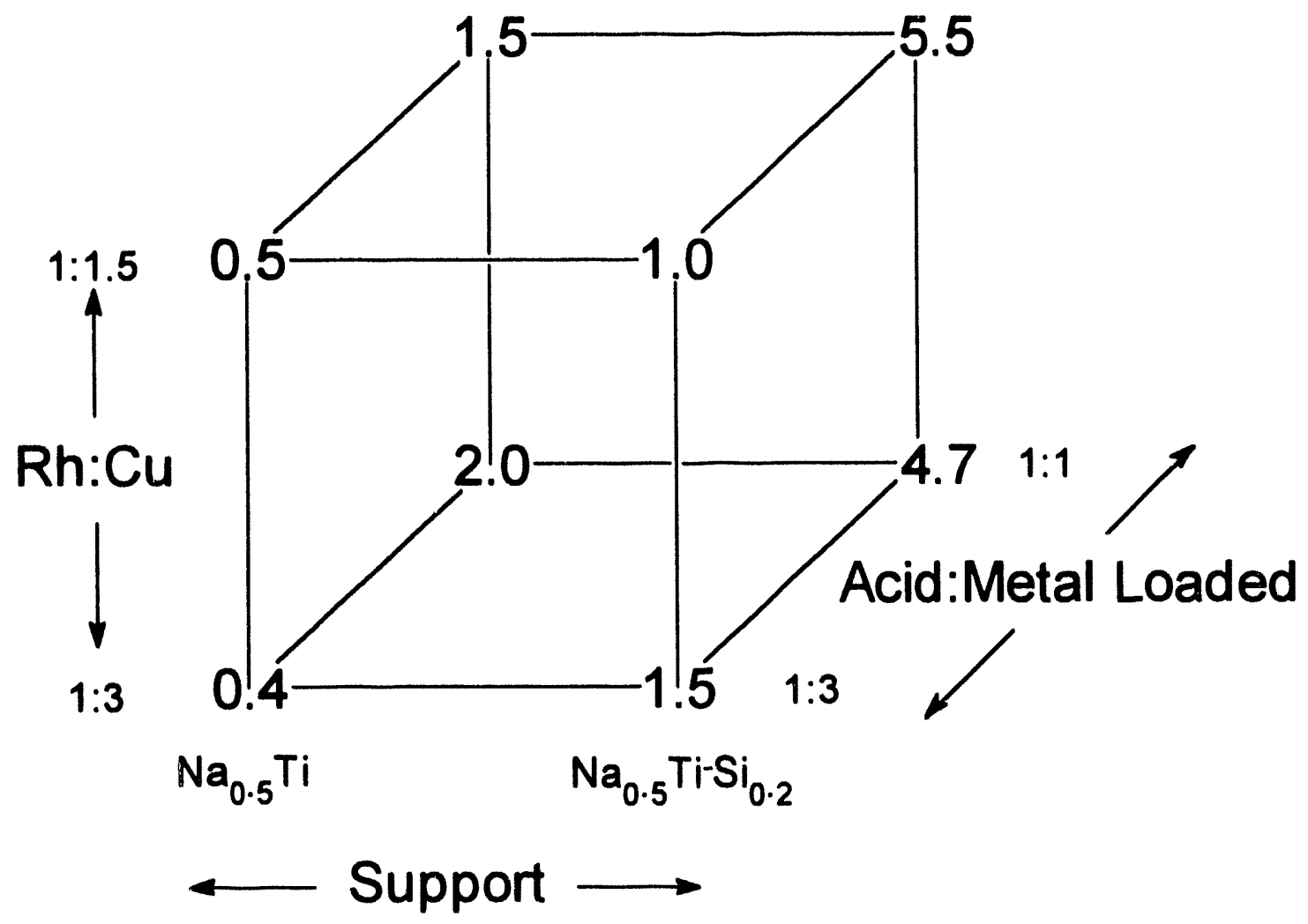

Figure 6. Ratio of GC peak area of 2-octanone to 1,1 diethoxyethane (see text) as a function of catalyst composition (see Table IX.) for the fully heterogeneous catalysts CuRh \#1-A-1 - CuRh \#4-A-8. 


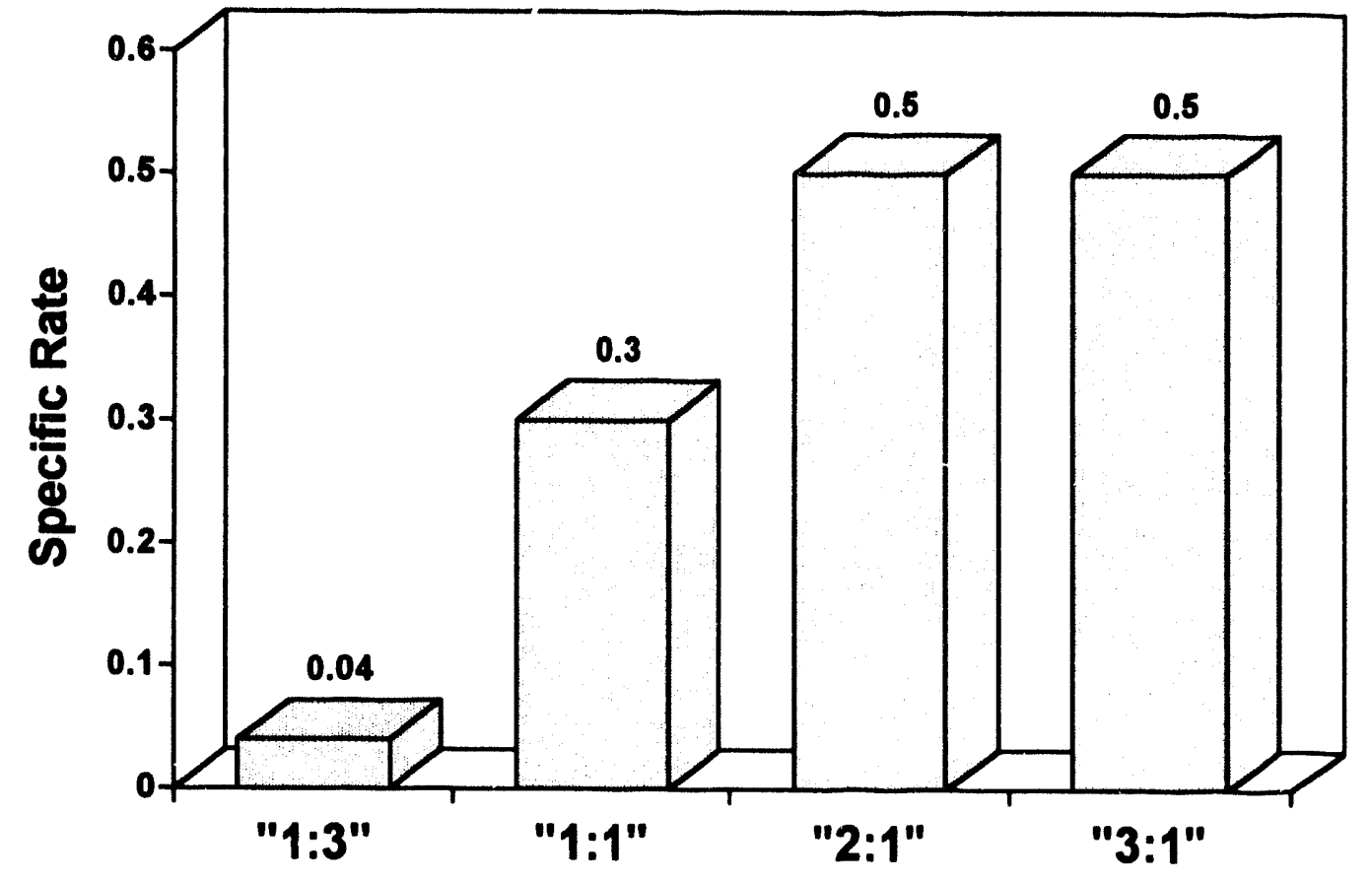

Figure 7. Effect of $\mathrm{HCl}$ content on oxidation activity for heterogeneous $\mathrm{CuRh}$ catalysts. $\mathrm{HCl}$ content is expressed as the ratio of $\mathrm{HCl}$ treated material to metal loaded material mixed to form the catalyst. All catalysts had a $\mathrm{Cu}: \mathrm{Rh}$ ratio of 1.5:1. Experiments were performed at $60^{\circ} \mathrm{C}$ in ambient air. 


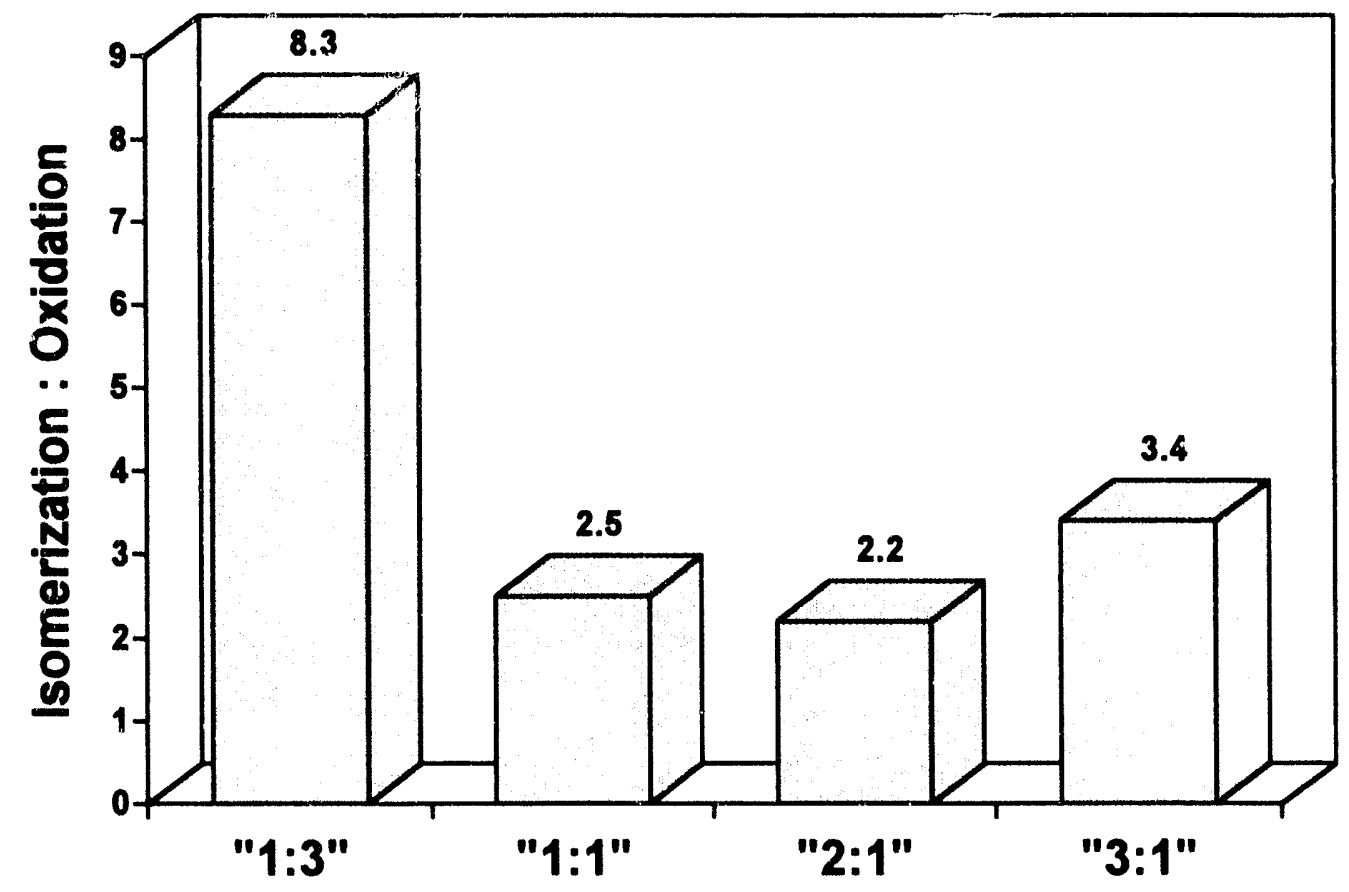

Figure 8. Effect of $\mathrm{HCl}$ content on ratio of isomerization to 2-octanone formation for heterogeneous CuRh catalysts. $\mathrm{HCl}$ content is expressed as the ratio of $\mathrm{HCl}$ treated material to metal loaded material mixed to form the catalyst. All catalysts had a $\mathrm{Cu}: \mathrm{Rh}$ ratio of 1.5:1. Experiments were performed at $60^{\circ} \mathrm{C}$ in ambient air. 


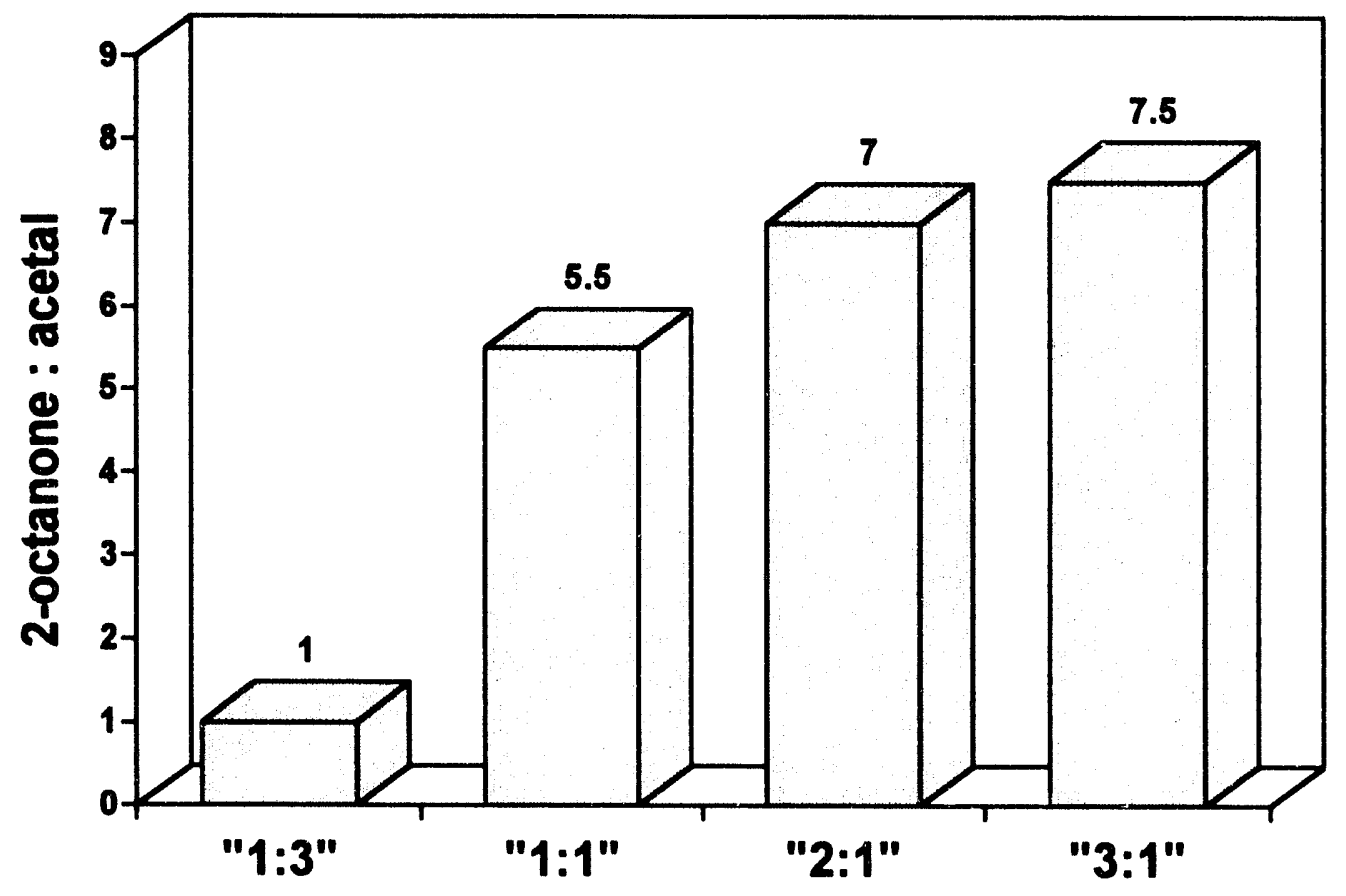

Figure 9. Effect of $\mathrm{HCl}$ content on ratio of $\mathrm{GC}$ pc.sk area of 2-octanone to 1,1 diethoxyethane (see text) for heterogeneous $\mathrm{CuRh}$ catalysts. $\mathrm{HCl}$ content is expressed as the ratio of $\mathrm{HCl}$ treated material to metal loaded material mixed to form the catalyst. All catalysts had a $\mathrm{Cu}: \mathrm{Rh}$ ratio of $1.5: 1$. Experiments were performed at $60^{\circ} \mathrm{C}$ in ambient air. 




Figure 10. Effect of volume ratio of ethanol to 1-octene in solution on oxidation activity of $\mathrm{CuRh} \# 4-\mathrm{A}-10$. Experiments were performed at $70^{\circ} \mathrm{C}$ in ambient air. 
- ل!e quətqure u! O.0L te

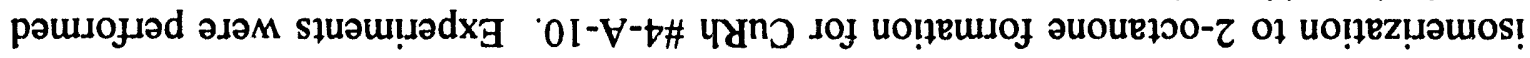






Distribution:

Shell Development Co. (6)

T. F. Brownscombe

J. D. Colthart (2)

D. Durbin

T. C. Forschner

P. Morse

Westhollow Research Center

P. O. Box 1380

Houston, Tx 77251-1380

6200 D. E. Arvizu

6211 Allen Sault

6212 Howard Stephens

6212 Tim Gardner

6212 Steve Lott

6212 Linda McLaughlin

6212 Jim Miller (10)

6611 Ed Weinbrecht (10)

7141 Technical Library (5)

7613-2 Document Processing for DOE/OSTI (8)

7151 Technical Publications

8523-2 Central Technical Files 

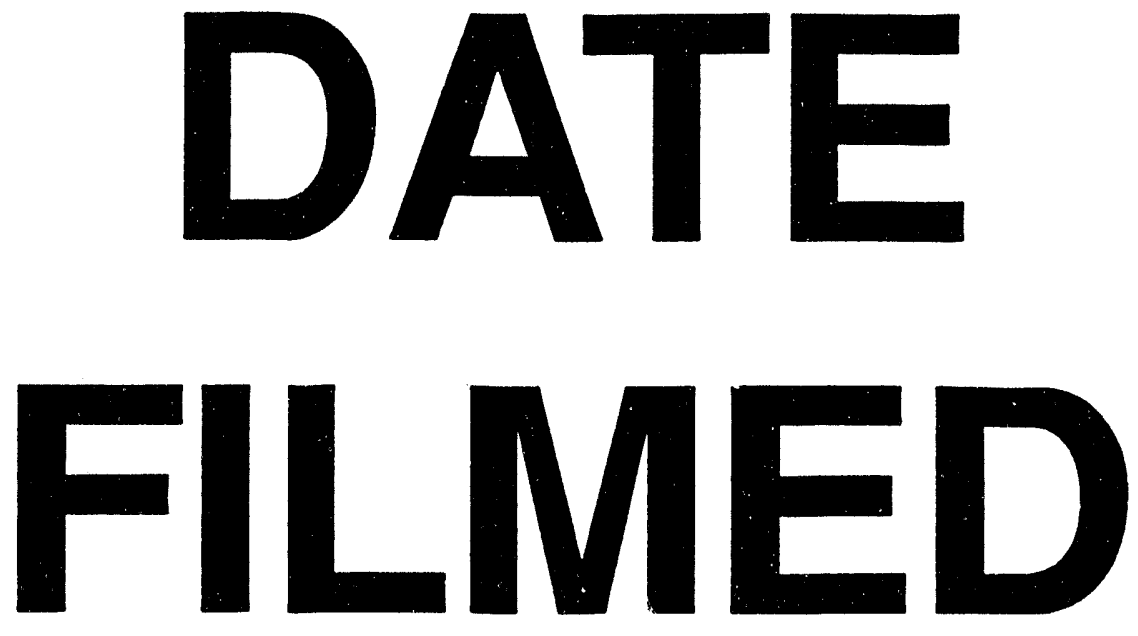

$10 / / 9 / 94$

